BORBÁLA GULYÁS*

\title{
PREVIOUSLY UNKNOWN CHARTERS IN BOOKLET FORM BY THE GALLIGRAPHER GEORGE BOCSKAY ${ }^{1}$
}

\begin{abstract}
In this paper, the author examines the script forms and ornaments of five works by the Hungarian calligrapher, George Bocskay $(\dagger 1575)$, which have so far eluded researchers' attention. All are manuscript charters on parchment, issued in Vienna in the second half of the sixteenth century by Habsburg rulers (some in their capacity as kings of Hungary), and all are of extremely high quality, decorated with elaborate calligraphy. Justification for presenting them together derives from their similar format: they are not conventional, single folio charters, but were all produced in booklet form. Since these manuscripts were closely connected with George Bocskay's time as an official at the Viennese Court, the paper provides an overview of the different stages of his career there, based primarily on recently unearthed archive sources. For thirty years Bocskay worked at - and was promoted through the ranks of - the Hungarian Court Chancellery, which was the official government body within the composite state of the Habsburg Monarchy with responsibility for issuing charters pertaining to the Kingdom of Hungary. Among the official documents issued here by the Habsburg rulers, in their capacity as kings of Hungary, the most important from an art historical aspect are the letters patent issued to members of the Hungarian nobility, which featured a miniature of the granted coat of arms and usually also calligraphic decoration. Based on the author's latest research, several examples of such decoration can now be attributed to the calligrapher, whose activity even led to the creation of a calligraphic school within the Chancellery. This paper presents three previously unknown manuscripts, namely the letters patent issued to Márk Horváth-Stanchich (1558), János Pethő de Gerse (III) (1572), and János Liszthy (1573); the identity of the master who made the miniatures on the two latter documents is also suggested (Donat Hübschmann). Furthermore, the paper provides clarification of the reading of a Bocskay signature found on a letters patent (grant of barony) issued to Miklós Oláh (1558-60), already described in the literature as a work by the calligrapher. Also on the basis of relevant archive sources, the author goes on to opine that, in addition to his official positions at the Chancellery, Bocskay also served in another role within the Viennese Court, which can best be defined as "calligrapher to the ruler." It was for such services that Ferdinand I of Habsburg, in his capacity as Hungarian king, also bestowed upon him the nominal title of royal courtier (in Latin: aulae regiae familiaris / aulicus). In the author's opinion, the artist, as "calligrapher to the ruler." was also given the commission to decorate two further important charters, also discussed in this paper, both ratifying roval marriages between Habsburg archduchesses and Italian noble houses. Issued in Vienna in 1565 by Emperor Maximilian II of Habsburg and Archdukes Ferdinand and Charles, one charter ratified the marriage between Archduchess Barbara and Alfonso II d'Este, while the other ratified the marriage between Archduchess Joanna and Francesco Medici.

Keywords: George Bocskay, calligraphy, letters patent, marriage ratification charter, writing model book, Hungarian Court Chancellery, Ferdinand I of Habsburg, Maximilian II (I) of Habsburg, Miklós Oláh, Márk Horvát-Stanchich, János Pethő de Gerse (III), János Liszthy, Donat Hübschmann, János Zsámboky (Johannes Sambucus), humanistic and Gothic scripts, Vespasiano Amphiareo, Ludovico degli Arrighi, Giovanbattista Palatino, Johann Neudörffer the Elder, entrelac Fraktur initial ("Flechtwerkinitial"), grotesque, scrollwork ("Rollwerk"), arabesque, entry, wedding festival, Archduchess Barbara of Austria, Alfonso II d'Este, Torquato Tasso, Il tempio d'amore, Archduchess Joanna of Austria, Francesco Medici, Cosimo I Medici, Palazzo Vecchio. Vincenzo Borghini, Giorgio Vasari
\end{abstract}

The Hungarian calligrapher George (in Hungarian: György) Bocskay $(† 1575)$ owes his international fame mostly to the two writing model books (1561-62, 1571-73) that were illu-

* Borbála Gulyás PhD, Institute of Art History, Research Centre for the Humanities, Hungarian Academy of Sciences, Budapest; e-mail: gulyas.borbala@btk.mta.hu minated in the 1590s by the Flemish artist Joris Hoefnagel (1542-1601) for Emperor Rudolf II (1576-1612). ${ }^{2}$ International researchers also ascribe a role to Bocskay in the execution of the acid-etched inscriptions all'antica of the sepulchral monument of Emperor Maximilian I in Innsbruck (1563-68). ${ }^{3}$ What is less well-known, however, is that the calligrapher was also respon- 

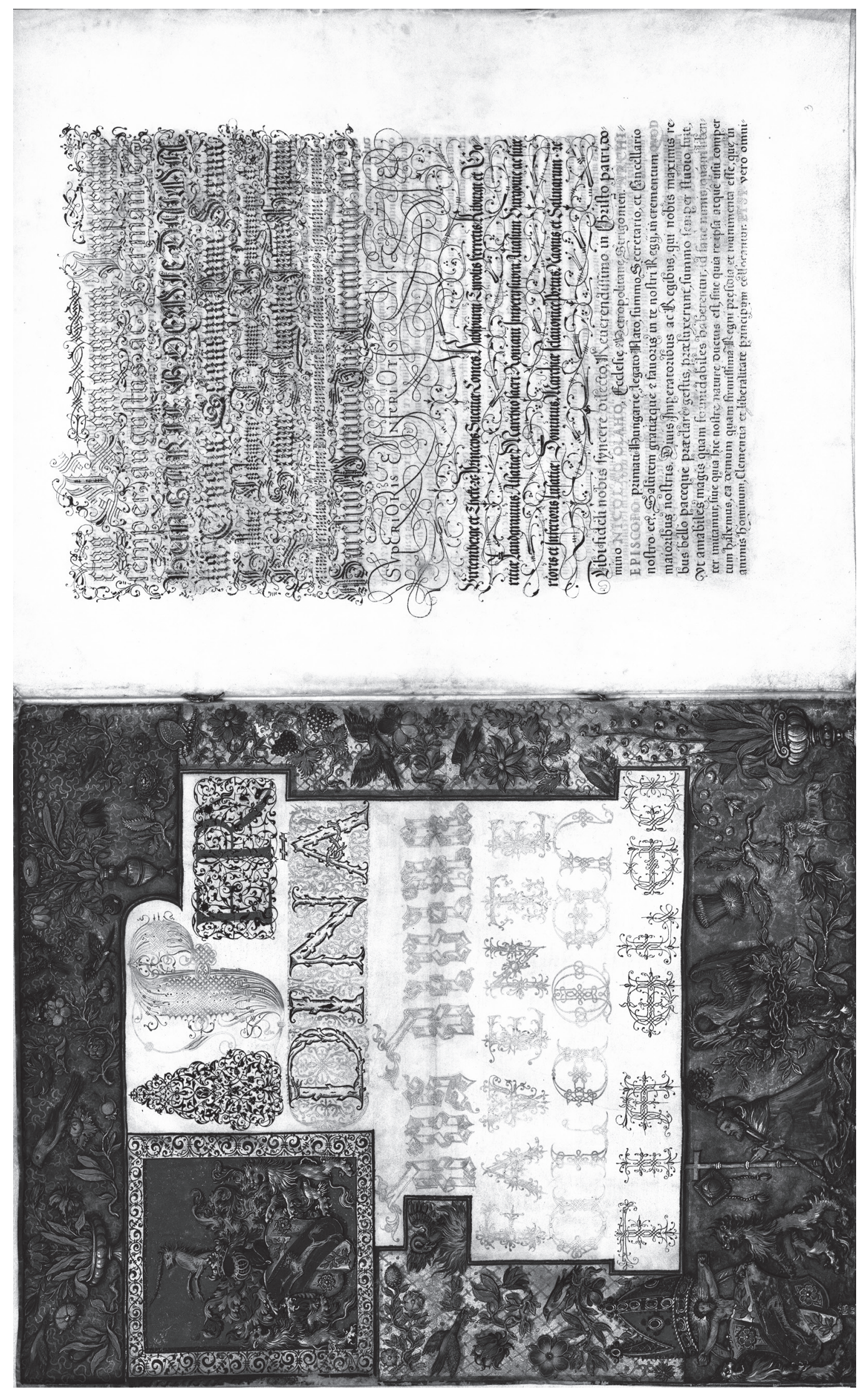

Fig. 1. George Bocskay: Frontispiece of the letters patent of Miklós Oláh, 1558-60; MNL OL, P 108, Rep. 2-3, Fasc. K, No. 163. fols. 2v-3r (photo by MNL OL, 2016) 


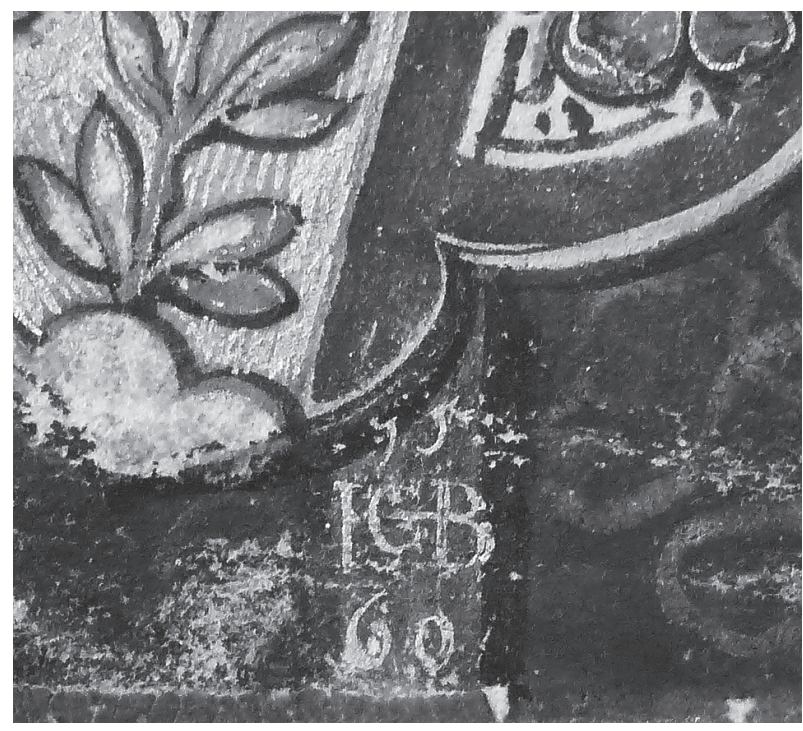

Fig. 2. Signature of George Bocskay ("15 FGB 60") on the letters patent of Miklós Oláh, 1560;

MNL OL, P 108, Rep. 2-3, Fasc. K, No. 163. fol. 2v, detail (photo by the author, 2011)

sible for decorating a considerable number of charters. By the beginning of the twentieth century, the name Bocskay was already mentioned in the Hungarian literature in connection with a variety of letters patent granting armorial bearings (hereafter: letters patent), although many of the pieces attributed to him actually originated only after his death. ${ }^{4}$ Later, the elaborately decorated letters patent of Miklós Oláh (1558-60, Fig. 1) came under the spotlight of research. ${ }^{5}$ This work even features the calligrapher's signature (Fig. 2), which is also briefly described in this paper. In recent years, in addition to the Oláh letters patent, my research has uncovered a significant number of other, previously unknown charters that can be included in the calligrapher's ouvre. Outstanding among them are five extremely richly decorated manuscripts in book- let form, commissioned by members of the Hungarian clerical and lay elites, or by the Habsburg ruler, to mark important occasions. This paper now presents these previously unexamined works, which are all of exceptional quality.

The artist's ouvre includes a large number of charters, most of which were letters patent (e.g. grants/confirmations/augmentations of arms, grants of barony) issued to Hungarian nobles. The reason for this can be found in George Bocskay's thirty-year career at the Hungarian Court Chancellery $^{6}$ in Vienna. This was the central governmental office of the Kingdom of Hungary within the composite state of the Habsburg Monarchy: it was here that Habsburg rulers, in their capacity as kings of Hungary, issued documents (such as letters patent) that had a bearing on the internal affairs of Hungary. Based on my research in the archives, it is highly likely that Bocskay first came to the Chancellery in $1545^{7}$ as personal scribe to the deputy chancellor, the afore-mentioned Miklós Oláh (1493-1568). (For an overview of all the paid positions filled at court by Bocskay, see Fig. 3.) Bocskay's subsequent appointment as Hungarian court secretary was an important promotion for him, as it meant that he was now an employee of the state. According to other recently unearthed archive sources, this took place in $1554,{ }^{8}$ because from then on he received an annual salary for this from the Hungarian Court Chamber. (Fig. 3) He subsequently held this office for the rest of his life, and he was also appointed royal councillor at some point between 1562 and 1565.' (Fig. 3) During this period the Hungarian Court Chancellery operated in Miklós Oláh's own house in Vienna (Wallnerstraße), on the site where the seventeenth-century Palais Esterházy now stands. ${ }^{10}$ The head of

\begin{tabular}{|l|l|l|l|l|l|}
\hline Position & Title in Latin & Title in German & Location & Dates & Paid by \\
\hline $\begin{array}{l}\text { scribe of the } \\
\text { Hungarian } \\
\text { Chancellor }\end{array}$ & notarius / scriba & Kanzleischreiber & $\begin{array}{l}\text { Hungarian Court } \\
\text { Chancellery }\end{array}$ & $1545-1554$ & $\begin{array}{l}\text { Miklós Oláh Deputy } \\
\text { Chancellor / Chancellor } \\
\text { / High Chancellor } \\
\text { (Vienna) }\end{array}$ \\
\hline $\begin{array}{l}\text { Hungarian court } \\
\text { (royal) secretary }\end{array}$ & $\begin{array}{l}\text { secretarius } \\
\text { Hungaricus }\end{array}$ & $\begin{array}{l}\text { Ungarischer } \\
\text { Hofsekretär }\end{array}$ & $\begin{array}{l}\text { Hungarian Court } \\
\text { Chancellery }\end{array}$ & $1554-1575$ & $\begin{array}{l}\text { Hungarian Chamber } \\
\text { (Pozsony) }\end{array}$ \\
\hline $\begin{array}{l}\text { Hungarian / } \\
\text { royal councillor }\end{array}$ & $\begin{array}{l}\text { consiliarius regius / } \\
\text { Hungaricus }\end{array}$ & Ungarischer Rat & $\begin{array}{l}\text { Hungarian (Royal) } \\
\text { Council }\end{array}$ & $1562 / 65-1575$ & $\begin{array}{l}\text { Hungarian Chamber } \\
\text { (Pozsony) }\end{array}$ \\
\hline royal courtier & $\begin{array}{l}\text { aulae regiae } \\
\text { familiaris / aulicus }\end{array}$ & Hofdiener & $\begin{array}{l}\text { Hungarian royal } \\
\text { court }\end{array}$ & $1559-1575$ & $\begin{array}{l}\text { Hungarian Chamber } \\
\text { (Pozsony) }\end{array}$ \\
\hline courtier & aulicus & Hofdiener & $\begin{array}{l}\text { the joint Habsburg } \\
\text { court }\end{array}$ & $1563-1575$ & $\begin{array}{l}\text { Court's Paymaster's } \\
\text { Office / Hofzahlamt } \\
\text { (Vienna) }\end{array}$ \\
\hline
\end{tabular}

Fig. 3. Paid positions occupied by George Bocskay in Vienna 
the Chancellery was the high chancellor, a position that came with the office of Archbishop of Esztergom, but daily operations were run by the chancellor and the deputy chancellor, based permanently in Vienna. Within the Chancellery, the Hungarian court secretaries occupied positions of influence: they participated in preparing the documents, effectively standing in for the chancellor and deputy chancellor, and they even had access to the ruler. In those days, two people were generally employed as Hungarian court secretaries, both picked from the highest echelons of the Hungarian humanist ecclesiastical elite and the secular intelligentsia. Bocskay's fellow secretaries included, for example, the humanist András Dudith (1533-1589), the future leader of the Chancellery, János Liszthy ( +1577 , Figs. 7-10), and the historians Miklós Istvánffy (1538-1615) and Ferenc Forgách (1535-1577) ${ }^{11}$

George Bocskay spent thirty years as an officer of the Hungarian Court Chancellery, assisting in arranging a wide range of official documents. The most important, from an art historical point of view, are the letters patent, which were drawn up on parchment, and fitted with a miniature depicting the granted coats of arms, usually accompanied with calligraphic decoration. ${ }^{12}$ If the king conferred a coat of arms upon a Hungarian nobleman (grant/confirmation/augmentation of arms), or elevated him to a higher rank, such as a barony, the letters patent certifying such royal acts were issued at the Chancellery. The costs - the tax, the materials used (parchment, cord, gilding, etc.), the fees for composing the text, the miniature of the coat of arms and, if required, any additional painted or calligraphic decoration - were covered by the grantee. ${ }^{13}$ During the decades of his tenure, Bocskay had ample opportunity to make good use of his skills as a calligrapher. Based on my research, a large number of the letters patent that have survived from his period of service at the Chancellery (154575) can be attributed to him. Bocskay's decorative prowess was in high demand from members of the Hungarian ecclesiastical and lay elites. Evidence of this comes in the form of a letter, written in 1557 by a Hungarian magnate, János Révay, in which he stated that the new letters patent for the barony granted to the family "should be illuminated with gold lettering by Bocskay" ("ut per Boczkaj aureis li[tter] is illuminentur"). ${ }^{14}$
Although this particular manuscript has not survived, an idea of the calligraphic artistry Bocskay used may be formed from looking at the other letters patent (grants of barony) that are presented below. (Figs. 1, 4) It is worth noting that during Bocskay's time in office, the quality of the letters patent issued by the Chancellery fluctuated greatly, so only certain works can be attributed to him. Nevertheless, it is striking how many of the other (less excellent) manuscripts also feature the same script forms and ornaments that Bocskay frequently employed. This implies that the calligrapher, through his work at the Chancellery, established a kind of school, whose most distinctive decorative elements - albeit in reduced form - continued to thrive on letters patent even into the seventeenth century.

Below I present two further manuscripts (Figs. 11-12) which, in my opinion, can also be attributed to the calligrapher, but which - though also originating in Vienna - were not issued by the Hungarian Court Chancellery. They are marriage charters ratifying the dynastic marriages of two Habsburg archduchesses. It is my view that Bocskay received the commission to decorate these highly important documents directly from the ruler himself, because within the court in Vienna, Bocskay also held a further, privileged position, which can best be defined as "calligrapher to the ruler."

Evidence of this is revealed in numerous archive sources. The earliest known to us at present is a document (letters patent [grant of lands]) from $1551,{ }^{15}$ which was issued by Ferdinand I (King of Hungary: 1526-1564; Holy Roman Emperor: 1556/58-1564). In this document Bocskay is referred to as scribe to the Chancellery and to Ferdinand I ("Notarius maioris Cancellariae nostrae Hungaricae et scriptor noster"). This latter role was emphasised by the calligrapher himself in his early signatures as well. In the writing model book he made for Ferdinand I (1561-62), he declared, in an extraordinary labyrinth of blackletters derived from the printed manual of Wolfgang Fugger, ${ }^{16}$ that it had been "written in Vienna by George Bocskay [...] scribe to the king and royal courtier, in eternal memory of the art of the pen." ${ }^{17}$ He identified himself as the calligrapher or "scribe to Ferdinand I," even though by that time he had long ceased to be a scriba, having already been promoted to the posi- 
tion of secretarius at the Chancellery (cf. Fig. 3); he also used a humanist trope to declare that the memory of calligraphy, the ars scribendi, would survive for eternity.

At the same time, alongside the title of "scribe to the king," he added the court title of "aulicus" to his signature, which, I believe, was also in honour of his activity as a calligrapher. The title of royal courtier (aulae regiae familiaris / aulicus) had been used in the Hungarian royal court since the Late Middle Ages, but by the reign of Ferdinand I it was nothing more than a nominal title, granted by the king in exchange for a diverse range of official, intellectual or financial services. ${ }^{18}$ According to a recently discovered letters patent, this title was conferred upon Bocskay in $1559 .{ }^{19}$ Interestingly, in this document he is once again referred to as "scribe of the Hungarian Chancellery" ("scriba maioris Cancellariae nostrae Hungar[icae]"), even though he had occupied the position of secretarius since 1554 (cf. Fig. 3). This allows the conclusion to be drawn that the title of royal courtier was granted by the king, Ferdinand I to the calligrapher, that is, the "scribe of the Hungarian Chancellery," as a reward for his artistic achievements. Bocskay also received an additional annual salary from the Hungarian Court Chamber, which was paid, in accordance with a royal instruction of $1561,{ }^{20}$ to the "royal courtier and scribe to Ferdinand I" ("aulicus et scriba noster") (cf. Fig. 3). In the light of this knowledge, it is easy to see why Bocskay was so keen on repeatedly highlighting his newly granted title in the writing model books he produced for Ferdinand I (1561-62, 1562), because he had earned it from the ruler in recognition of his expertise at calligraphy. In addition to the example cited above, Bocskay refers to himself in these works as "royal courtier" on a further three occasions. $^{21}$

It appears that Bocskay was allowed to keep his role as "calligrapher to the ruler" even after Ferdinand I was succeeded on the throne by Maximilian (as King Maximilian I of Hungary: 1563-1576; as Maximilian II, Holy Roman Emperor: 1564-1576). Between 1563 and 1568 Bocskay made the all'antica inscriptions on the sepulchral monument of Emperor Maximilian I in Innsbruck..$^{22}$ In 1565 he decorated the two afore-mentioned marriage ratification charters (Figs. 11-12), which will be discussed in detail later. Bocskay dedicated his third writing model book to Maximilian II (I) (1571-73). ${ }^{23}$ It was almost certainly as a result of his activities as a calligrapher that he was awarded yet another annual salary from 1563 onwards. Bocskay's name appears regularly in the account books of the Court's Paymaster's Office, ${ }^{24}$ which registered the amounts paid to the "Hofdiener" (courtiers of the joint Habsburg court) in Vienna (cf. Fig. 3).

The manuscripts discussed here tell us not only about the commissioners and patrons of George Bocskay, but also in a broader sense about the network of personal connections he established in the Viennese court. All the charters were issued as official records of significant events, and they were ornately decorated, in accordance with their importance. However, as artworks of this kind, compared with writing model books, were much shorter in scope, the calligrapher was required to devote greater attention to decoration. As we will see, the artist fulfilled this demand by making simultaneous use of multiple letter forms and ornaments, creating a more decorative overall effect, which he enhanced further by applying alternating colours. It was as though he were producing an abstract of a more extensive work, where the different elements, originally organised into separate writing samples, were concentrated into a single, overarching decoration. Closer inspection of this unique, condensed method of decoration will enable an idea to be formed of what types of script and ornamentation the calligrapher particularly favoured, and how he exploited various ways of combining them to generate different permutations.

\section{Letters Patent Produced for the Hungarian Ecclesiastical and Lay Elites}

The most numerous group of charters that can be attributed to George Bocskay consists of the letters patent issued by the Hungarian Court Chancellery in Vienna. Of these, three manuscripts in booklet form (libelli, singular: libellus) are presented in detail below. The earliest is the letters patent (grant of barony) issued to Márk Horváth-Stanchich (1510s-1561). ${ }^{25}$ (Fig. 4) The grantee had filled a number of significant military positions in the Kingdom of Hungary, including captain general (1556-1557, 1558-1561) of 


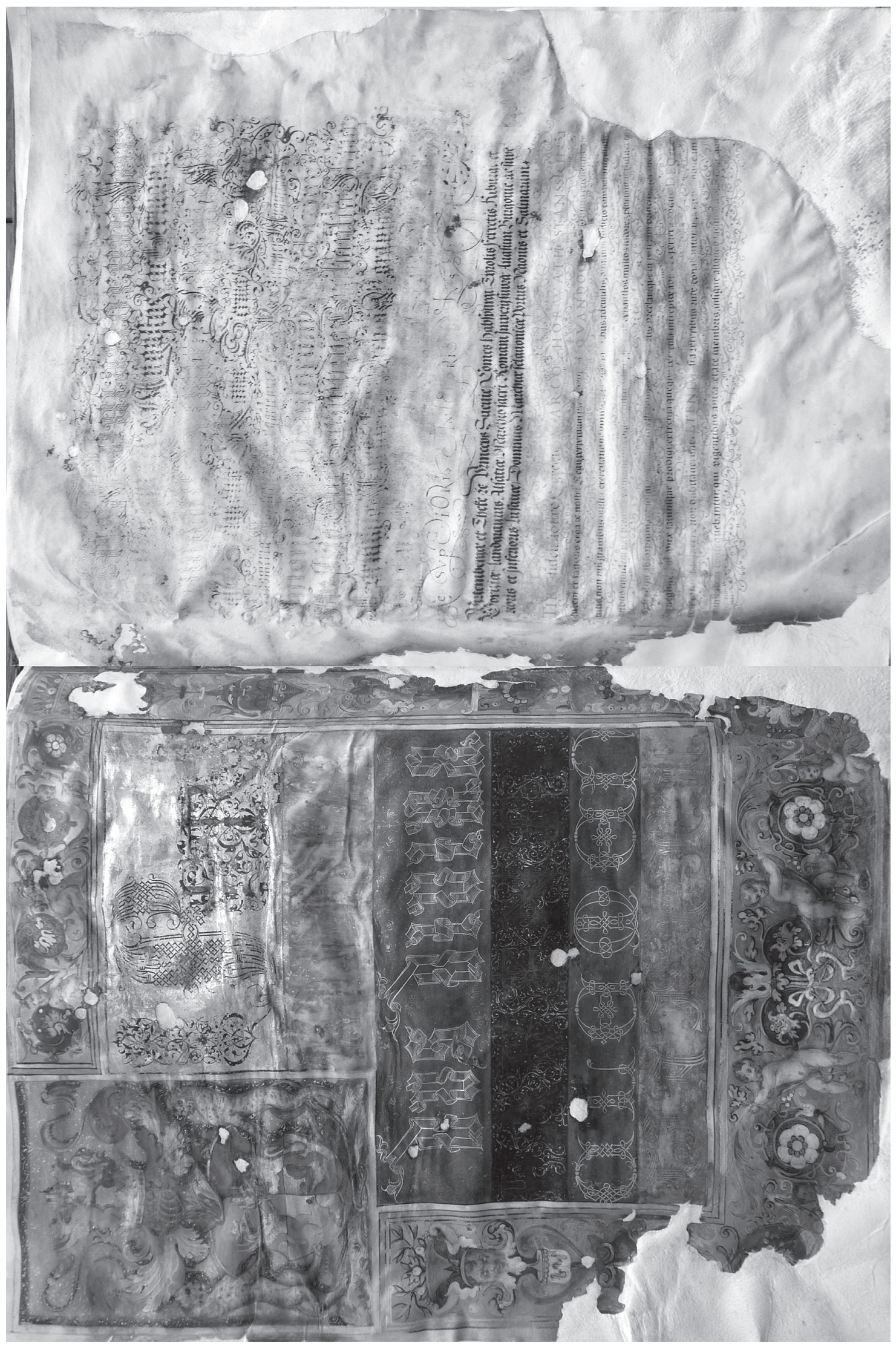

Fig. 4. George Bocskay: Frontispiece of the letters patent of Márk Horváth-Stanchich, 1558;

Levoča, Spišský archív v Levoči, Horváth-Stansith zo Strážok, bez signatúry. fols. 1v-2r (photo by the author, 2011) 
Szigetvár, one of the key frontier fortresses protecting the country from Ottoman invasion. ${ }^{26}$ In Bocskay's œuvre, this work can be regarded as the partner piece to the afore-mentioned letters patent (confirmation of arms, grant of barony) of Miklós Oláh (Figs. 1-2), ${ }^{27}$ because the systems of calligraphic decoration on the two manuscripts are almost entirely identical. Both are letters patent (grants of barony) issued in Vienna by Ferdinand I in the same year, 1558. However, whereas the Oláh libellus has survived in good condition, the Horváth-Stanchich libellus is severely damaged. ${ }^{28}$

In the introduction it was stated that the letters patent produced for Miklós Oláh (Figs. 1-2) was a work dated and signed by Bocskay. It was commissioned by the humanist prelate Miklós Oláh, Bishop of Zagreb (1543-1548), then Bishop of Eger (1548-1553), and later Archbishop of Esztergom (1553-1568), who directed the Hungarian Court Chancellery between 1543 and 1568 as deputy chancellor, chancellor and, finally, high chancellor. ${ }^{29}$ It was also mentioned that Bocskay almost certainly owed his position in Vienna to Oláh, for he had been brought there as the bishop's personal scribe (cf. Fig. 3). The calligrapher was therefore commissioned to produce this extraordinarily high quality letters patent by his first patron in Vienna and his immediate superior at the Chancellery. The close relationship between the calligrapher and his patron explains why the artist's signature appears on the document. The miniature painted coat of arms and borders occupy all of the margins on the left side of the two-page frontispiece of the letters patent. The coat of arms of Miklós Oláh is repeated in the border in the lower left-hand corner of the page. Behind the shield of this coat of arms can be seen a crucifix, whose lower upright bears the signature, written in gold. (Fig. 2) The previous literature ${ }^{30}$ has interpreted the signature as " 15 HGB 60," but it ought instead to be read as "15 FGB 60," standing for "15 Fecit Georgius Bocskay 60," that is, "Made by George Bocskay in 1560." The calligrapher used the same signature ("FGB") several times in the two writing model books produced around the same time (156162, 1562). ${ }^{31}$ Although the charter was issued in 1558 , it seems that the decoration was only completed two years later, in 1560 .

The remarkably similar Horváth-Stanchich letters patent $($ Fig. 4) must have been produced at the same time. The libellus manuscript in booklet form comprises two parchment bifolia. The two-page frontispiece is located on fols. $1 \mathrm{v}-2 \mathrm{r}$, and the text of the charter then continues on fol. 4r. Fols. 1r and 4v are blank. As with the Oláh letters patent (Fig. 1), the entire left side (fol. 1v) of the frontispiece is also covered with decorative borders, and there is a miniature of the coat of arms in the upper left-hand corner, at the start of the text. The border decoration consists of grotesque elements: above and below there are acanthus leaves and putti, while the two sides are made of candelabra with fruits and masks, placed over a gilded ground. I have not been able to identify any signature on this severely damaged page. The miniature of the coat of arms and the borders were painted by a skilled, as yet unidentified master.

Let us now turn to the calligraphic details of the manuscript. Like other calligraphers, George Bocskay derived his writing samples from printed writing manuals, which enjoyed great popularity at the time. Unlike most of his contemporaries, however, he was not always satisfied simply to copy different letter forms as they were, but liked to individualise them. Another feature that places him above others working in the same field was that he was equally at home producing humanistic and Gothic scripts, and he would even use these different hands in combination within the same text. Precedents for such diversity, and for the combined use of Italic and German letter forms on such a large scale, are nowhere to be found in any of the contemporary printed writing manuals or hand-written model books that have been handed down to posterity. This individuality can be seen on this work as well, which Bocskay produced using letter forms visible in the printed writing manuals of no less than three Italian authors - Ludovico degli Arrighi, Giovanbattista Palatino, Vespasiano Amphiareo - and one German - Johann Neudörffer the Elder. The authors listed were the most influential writing masters of the age, ${ }^{32}$ which demonstrates how widely read and up-to-date Bocskay was as a practitioner of his art. The same writing manuals were also demonstrably the primary sources for Bocskay's own calligraphic writing model books. ${ }^{33}$

On the left (fol. 1v, Fig. 4), the letter forms in the individual lines - apart from the last line 
- precisely follow the composition of the frontispiece in the Oláh libellus (Fig. 1). The only difference is that the letters in each line here have grounds of varying colour. This method of decoration is one of the characteristics of the calligrapher's writing model book of 1562, which also features variants of the same letter forms written on coloured grounds. ${ }^{34}$ The ground of the first line of the Latin text that begins with the word "Ferdinandus" is gold. It begins with an arabesque, which is slightly smaller and of a different shape to the similar ornament on the Oláh letters patent. This is succeeded by an entrelac Fraktur (German blackletter) $F$-initial with flourishes by Neudörffer ("Flechtwerkinitial"), ${ }^{35}$ and Roman inscriptional capitals (antiqua) in red, the latter also being supplemented by Bocskay with black arabesques. The ground of the second line is blue embellished with gold foliage, on which are aligned Amphiareo-style decorative Roman capitals in the form of tree trunks, ${ }^{36}$ written in silver. The third coloured unit of text is composed of Arrighi-style gold blackletters, formed from banderoles, ${ }^{37}$ whose ground is red, adorned with silver foliage. In the fourth line, with a black ground, we come across another type of Amphiareo's decorative Roman capitals, ${ }^{38}$ executed in silver, with the letters surrounded by gold patterning. The fifth line, written in gold, has a red ground once more, on which traces of silver ornament are still visible. Here Bocskay reverted to the Arrighi manual, using the Italian writing master's decorative interwoven capitals. ${ }^{39}$ The last line reiterates the blue-and-gold ground, although here the calligrapher employed the only element not included in the composition of the Oláh libellus, namely Italian Gothic capitals, written in silver.

The letter forms on the right side of the frontispiece (fol. 2r, Fig. 4) are also repetitions of the composition for the equivalent fol. $3 r$ in the Oláh libellus. (Fig. 1) There is a continued accumulation of humanistic and Gothic hands, including, among others, Palatino's rotunda (Italian Gothic), ${ }^{40}$ the same master's swashed Lettera Trattizata, ${ }^{41}$ and Amphiareo's blackletters with dotted $^{42}$ or zigzagged ${ }^{43}$ lines. Finally, this is followed by a German blackletter, which is replaced in the last line by bollatica (Italian Gothic script used in the Papal Chancellery). The text from there until the end is written using this same let- ter form, with the more important words highlighted in gold Roman capitals. Deviating from the Oláh libellus, however, there are also rich interlinear foliate ornaments in gold.

The two letters patent examined below were both produced more than a decade later, and were decorated in different ways. George Bocskay continued to combine humanistic and Gothic hands, but alongside the calligraphic details he also placed greater emphasis on varied ornamentation. The compositions of different arabesques and foliate ornaments become increasingly dominant decorative elements.

The letters patent (confirmation of arms, augmentation of arms) of János Pethő de Gerse (III) (1525-1578) (Figs. 5-6) was issued in 1572 by Maximilian II in his capacity as King Maximilian I of Hungary. ${ }^{44}$ The grantee was captain general of the major frontier fortresses Kassa (Kaschau, Košice, today Slovakia; 1557-1559) and Komárom (Komorn, Komárno, today Slovakia; 1563-1566), and was an important member of the Hungarian royal court attached to the Habsburg rulers, serving as royal Hungarian master of chamberlains between 1561 and 1578; he was also a member of the Hungarian Council, and one of the few Hungarians to keep his own house in Vienna. ${ }^{45}$ In this instance, then, the letters patent George Bocskay decorated with sophisticated calligraphy was made for one of his colleagues on the Council.

The letters patent in booklet form (libellus) was produced on parchment, and consists of four bifolia. Fols. 1 and 2 are blank. The miniature depicting the coat of arms is on fol. 3r. (Fig. 5) The "second frontispiece," with its calligraphic decoration, occupies the next two pages (fols. 3v-4r, Fig. 6). The text continues until fol. 7r, while fols. 7v and 8 are also blank. The Hungarian royal seal of the issuing king, Maximilian I (II), has survived on the charter, as has the purple, gold, green and blue silk cord attached to it.

The manuscript differs from other letters patent produced around the same time in that, instead of the miniature of the coat of arms being placed at the start of the text, as was standard practice at the Hungarian Court Chancellery, in this libellus it was placed before the text on a separate page (fol. 3r, Fig. 5). The composition stands out among the miniatures featured on other letters patent emerging from the Chancel- 
lery in the same period both for its decorativeness and for its complex iconography. The artist placed his signature $(D H)$ in gold in the lower left-hand corner, on the reverse of the shield that can be found there. In my opinion, there is a pos- sibility that the painter was Donat Hübschmann (before 1540-1583), ${ }^{46}$ who is known to have used a similar monogram consisting of two interweaving Roman capitals. The artist, who hailed from Leipzig, lived and worked in Vienna from the

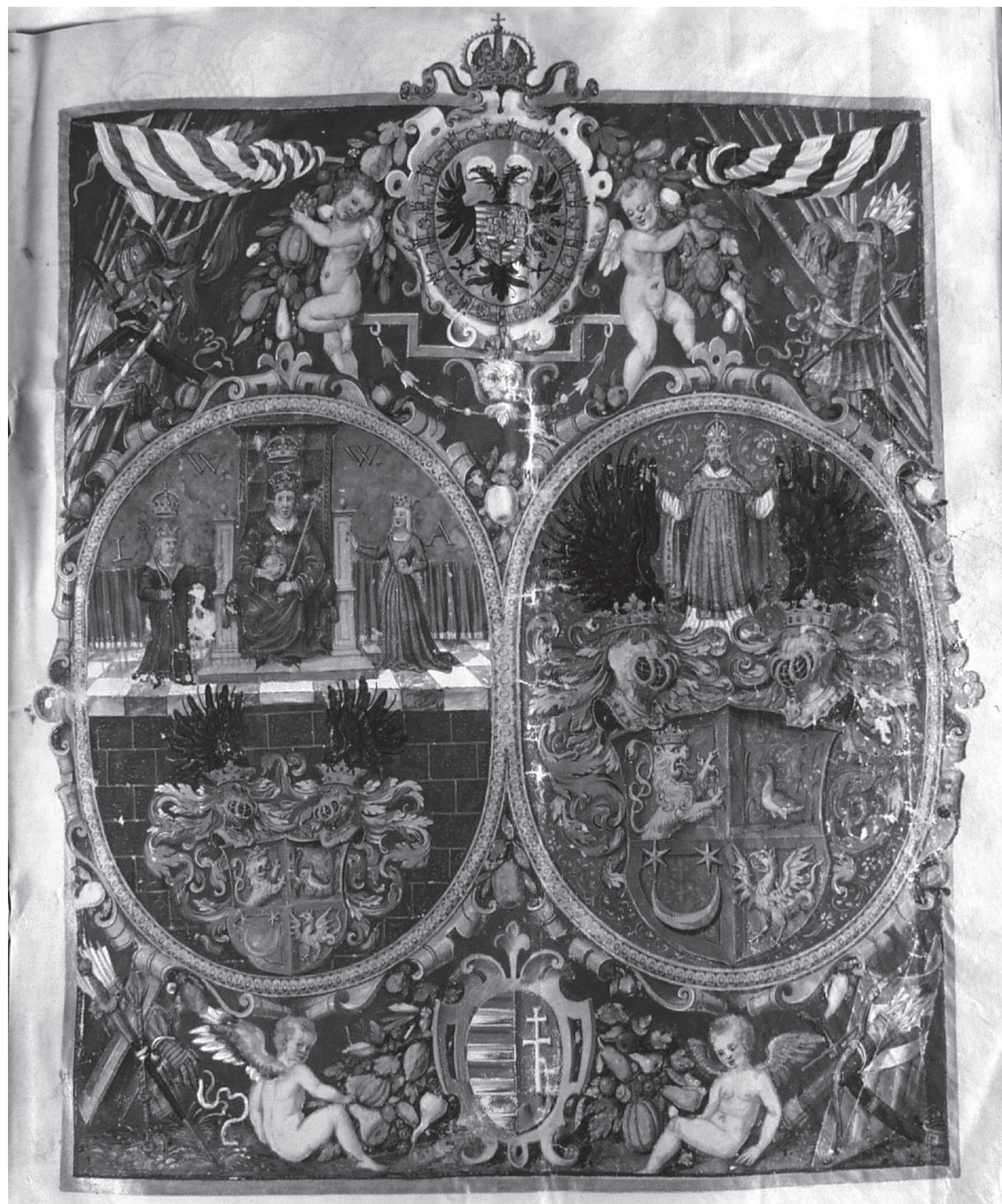

Fig. 5. Donat Hübschmann (?): Miniature of the granted coat of arms on the letters patent of János Pethő de Gerse (III), 1572; MNL OL, P 644, No. 2.1.1. fol. 3r (photo by MNL OL, 2008) 


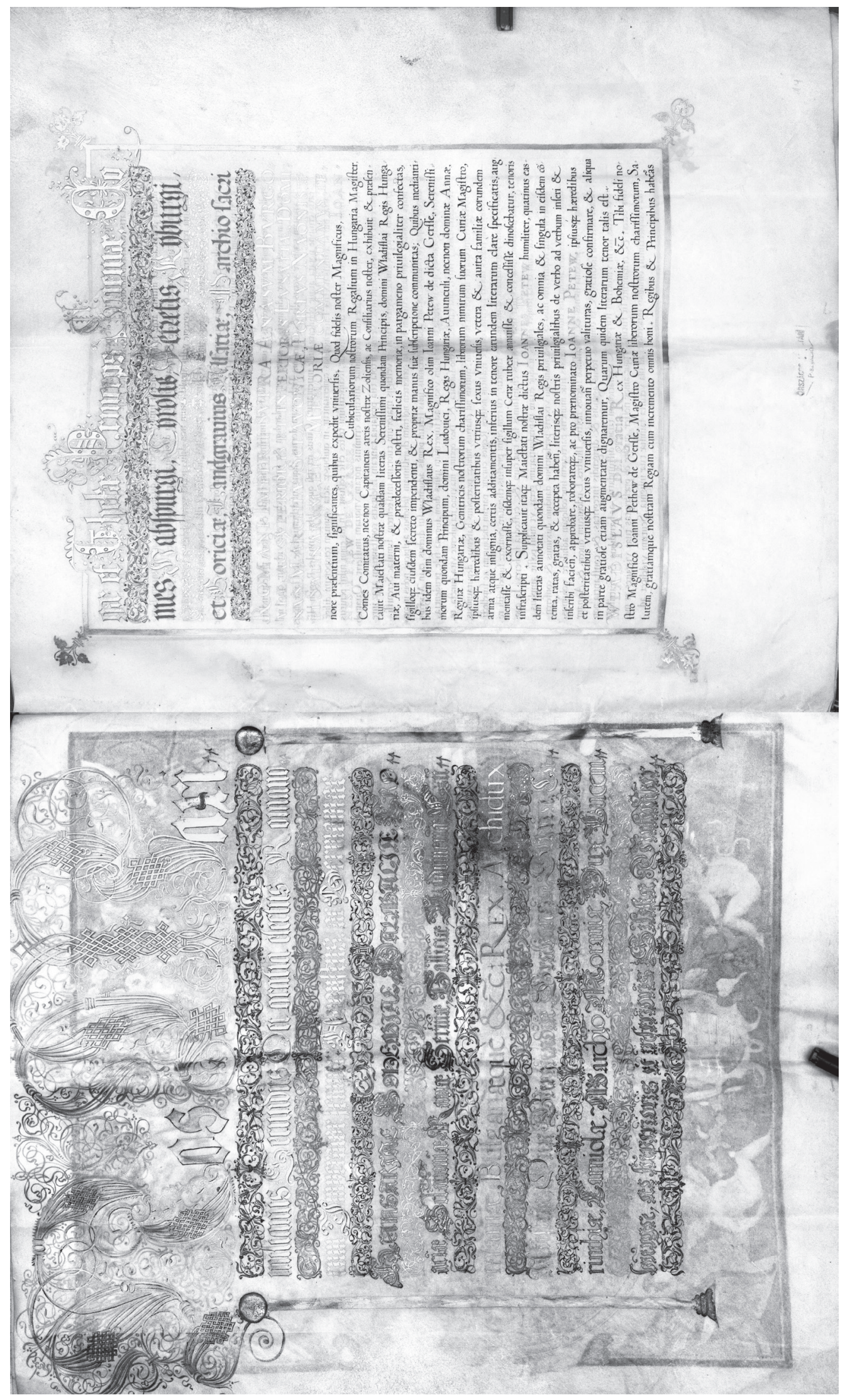

Fig. 6. George Bocskay: Frontispiece of the letters patent of János Pethő de Gerse (III), 1572; MNL OL, P 644, No. 2.1.1. fols. 3v-4r (photo by MNL OL, 2008) 
late 1550s until his death, even being granted citizenship rights there. Although he is primarily renowned for his woodcuts, the account books of the Court's Paymaster's Office inform us that he regularly worked as a painter for the court and for the city. ${ }^{47}$ The idea that Donat Hübschmann was commissioned by János Pethő de Gerse to decorate his letters patent seems increasingly likely in view of some of the artist's other commissioners, who included a number of important Hungarians in service at the Viennese court. In 1560, for example, Hübschmann made a copy of the engraved portrait of Miklós Oláh ( $c f$. Fig. 1), because the original copperplate (by Hans Sebald Lautensack, 1558) had become worn the new, updated woodcut is also signed $\mathrm{DH}^{48}$ Another woodcut attributed to the artist (and to his brother, Martin Hübschmann) was commissioned by the noted Hungarian court humanist, János Zsámboky (Johannes Sambucus, 15311584). The depiction was made for a broadsheet which was published in Vienna in 1563 on the occasion of the coronation in Pozsony (Pressburg, Bratislava, today Slovakia) of Archduke Maximilian as King of Hungary. ${ }^{49}$ The print contains a poem by Zsámboky, as well as the large woodcut by the Hübschmanns, which depicts in detail the events of the coronation. Zsámboky commissioned Donat Hübschmann again in 1566, when he republished, this time in Vienna, the first printed map of Hungary (Tabula Hungariae / Lazarus map, Ingolstadt, 1528), which the German master copied, once more signing the copperplate engraving with his monogram $D H .^{50}$

At the centre of the miniature (fol. 3r, Fig. 5), two oval cartouches contain the old Pethő coat of arms as well as the new one, with the augmentations granted by the letters patent. The old one is on the left, and was granted in 1507 by King Wladislas II Jagiellon of Hungary (1490-1516) to the then master of chamberlains, János Pethő de Gerse (I), the grandfather of the grantee of the letters patent in 1572. The original letters patent from 1507 has also survived..$^{51}$ This exquisite work of art occupies a prominent place in the history of Hungarian Renaissance miniature painting, and was produced in the miniature workshop that operated in the royal court in Buda ${ }^{52}$ Its most outstanding feature is that the coat of arms bears a portrait of King Wladislas II and his children, Anna and Louis (the future King Louis II Jagiel- lon of Hungary, 1516-1526). A copy of this was placed on the composition in 1572, and must have been directly based on the old letters patent. The new coat of arms placed alongside it also bears a portrait of the king, this time the Habsburg King Maximilian I (II) of Hungary. Two further coats of arms in oval cartouches are arranged along the vertical axis of the composition, with that of the Holy Roman Emperor above that of the King of Hungary, both references to Maximilian. Both are flanked by a garland of fruit and with two seated, winged putti. The composition as a whole - presumably in accordance with the wishes of the grantee - places the main emphasis on János Pethő de Gerse's military virtues. In the justification of the grant, the text describes at length how Pethö, together with his hussars (Hungarian light cavalry), served in the armed forces of Emperor Charles V (1530-1556/58), and participated in several of the battles against the Ottomans in Hungary. ${ }^{53}$ His achievements are represented visually by the mass of military trophies depicted in the composition.

The "second frontispiece," with its calligraphic decoration, which can be attributed to George Bocskay, occupies the next two pages (fols. 3v-4r, Fig. 6). On the left side (fol. 3v), the calligrapher once again chose the entrelac Fraktur initial of Johann Neudörffer the Elder ${ }^{54}$ for the most emphatic element in the Latin text that begins "Nos Maximilianus". We have already seen in his earlier manuscripts that this ostentatious script was one of his favourites for decorating letters patent. After the first line, done in gold Fraktur, each line of the text is written using different script forms, although the Italian and German hands dominate once more. The selected letters, aligned with the emphatic initials, were composed from different Gothic scripts. ${ }^{55}$ Only the fifth line consists of classic Roman capitals, matching the last few lines of the titulary of Maximilian I (II) on the opposite page, as well as the running text, also written in antiqua. Judging from its exceptional perfectionism, the latter was probably also executed by Bocskay. The colouring of the individual units of text in the opening alternates regularly, with two gold lines being followed by two silver lines, and so on. The interlinear spacing is filled with different arabesques and decorative foliate ornaments, whose colouring (black, silver, black with gold dots, and gold) also alternates according to a regular pattern. 
The text is contained within two gold column-like borders, each of which has a silver disc.

The calligraphic text of the titulary of Maximilian I (II) continues on the right side (fol. 4r).
The first line on the page, written in gold, is emphasised by the bollatica (Italian Gothic) initials $^{56}$ taken from Amphiareo's writing manual. The colouring of the letters is different from those

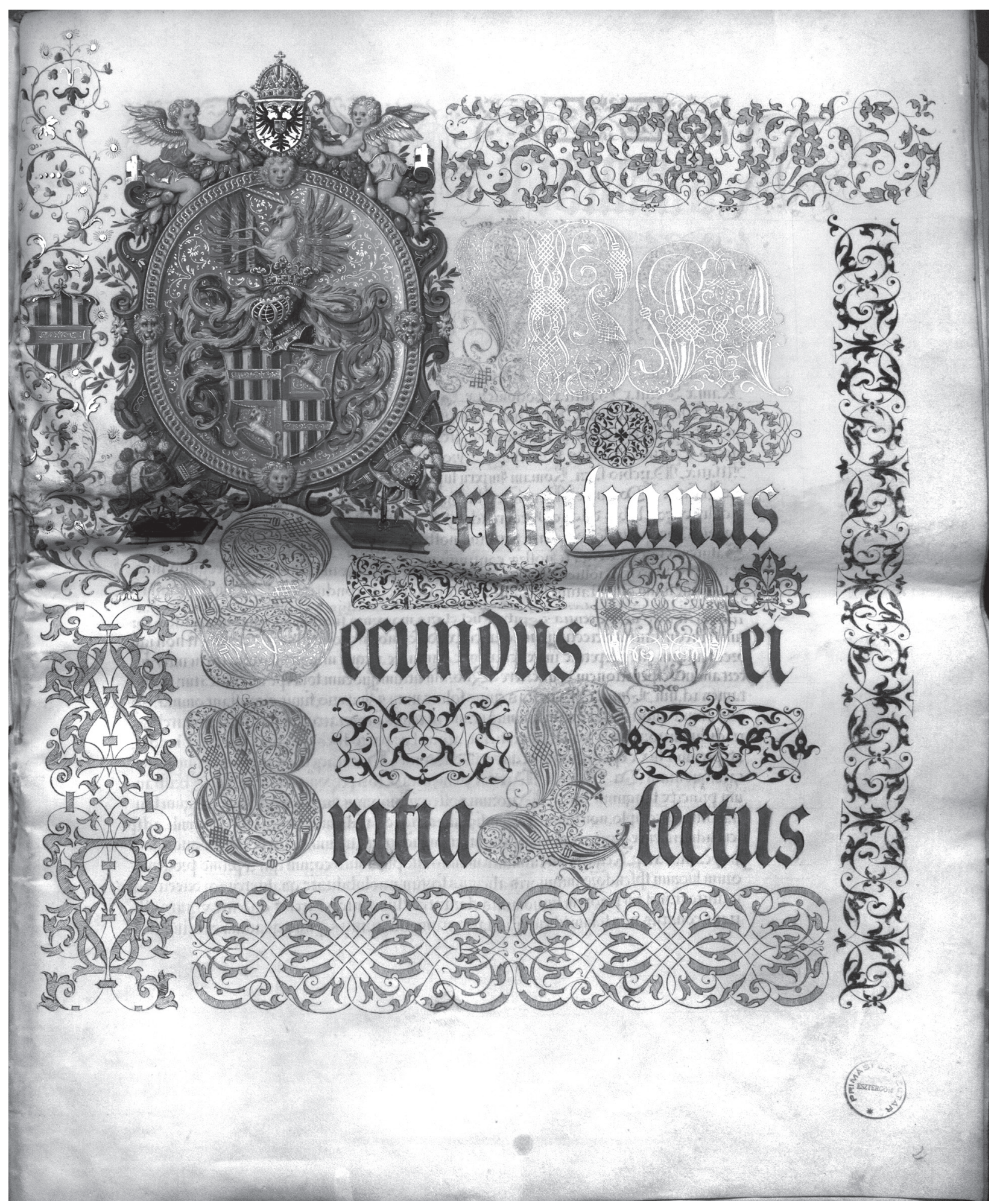

Fig: 7. George Bocskay: First page of the frontispiece of the letters patent of János Liszthy, 1573;

Esztergom, Primatial Archives, Acta Radicalia Cl. T, Nr. 168. fol. 2r (photo by Esztergom, Primatial Archives, 2012) 


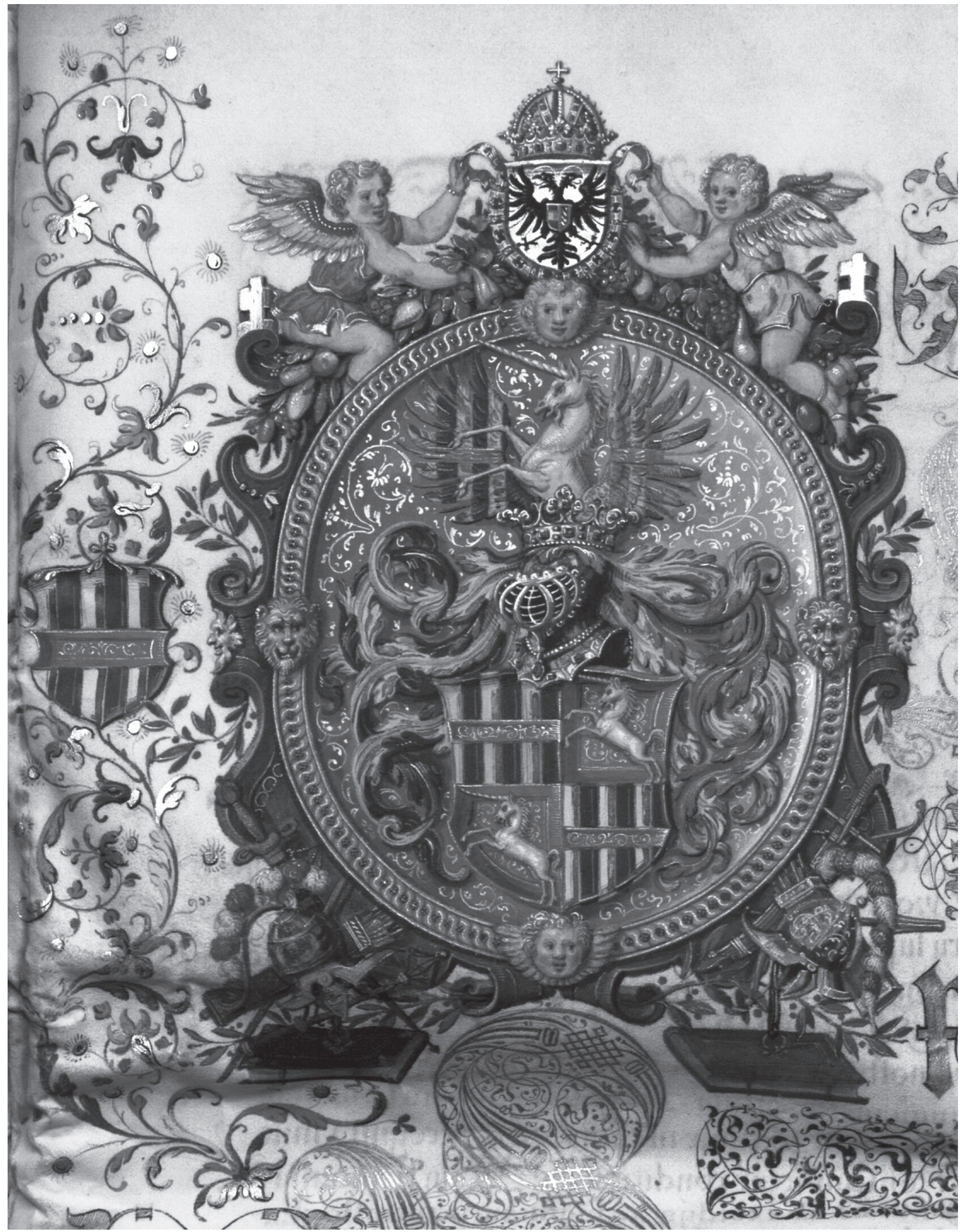

Fig. 8. Donat Hübschmann (?): Miniature of the granted coat of arms on the letters patent of János Liszthy, 1573; Esztergom, Primatial Archives, Acta Radicalia Cl. T, Nr. 168. fol. 2r, detail (photo by Esztergom, Primatial Archives, 2012) 


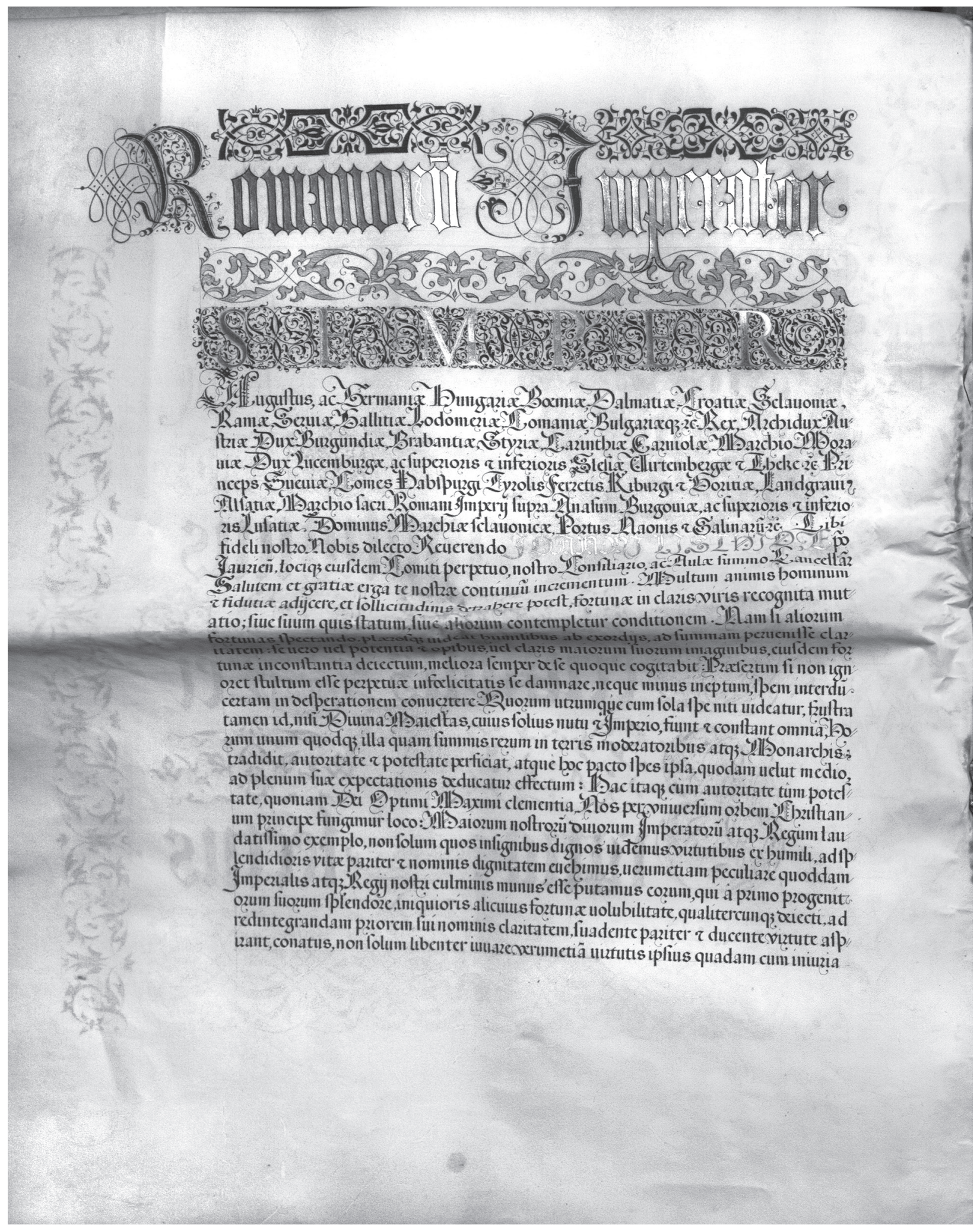

Fig. 9. George Bocskay: Second page of the frontispiece of the letters patent of János Liszthy, 1573; Esztergom, Primatial Archives, Acta Radicalia Cl. T, Nr. 168. fol. 2v (photo by Esztergom, Primatial Archives, 2012) 
on the preceding page, with the initial line in gold followed by German blackletters in blue and then a line of rotunda (Italian Gothic) in green, supplemented with gold initials. At the same time, the regular alternation in the colouring of the interlinear foliage ornaments also changes: an element in black with gold dots is followed by a plain gold one, and then another black one with gold dots. The text is surrounded with a simple gold frame, embellished with arabesques in each corner. The same border is repeated on all the other pages in the charter that feature writing (fols. $4 \mathrm{v}-7 \mathrm{r}$ ).

The last letters patent to be examined here (Figs. $7-10$ ) is also linked to one of the leading figures of the Hungarian royal court attached to the Habsburg rulers. The grantee of this letters patent (confirmation of nobility), 57 issued in Vienna in 1573, was the humanist János Liszthy (Johannes Listhius, †1577), an official at the Hungarian Court Chancellery, and later its leader. Liszthy served at the Chancellery for several decades alongside George Bocskay. He was first mentioned in 1553 as keeper of the seals (conservator sigilli) and Hungarian court secretary, and was later - like the calligrapher appointed councillor. He married Lukrécia Oláh, who was probably the illegitimate daughter of Miklós Oláh. After her death, he embarked on a career in the Church, becoming Bishop of Veszprém (1568-1572), then Bishop of Gyorr (1572-1577); after Miklós Oláh died, Liszthy took over the running of the Chancellery, first as deputy chancellor (1568-1573), and then as chancellor (other sources say high chancellor) $(1573-1577))^{58}$ This means that Bocskay produced this elaborately decorated charter for one of his former colleagues at the Chancellery, who had in the meantime risen to become its head.

The libellus in booklet form consists of three parchment bifolia. The seal of the Hungarian King Maximilian I (Maximilian II, Holy Roman Emperor) has survived intact, as has the gold-andsilver cord. Fols. 1, 5 and 6 are blank. The frontispiece is on fol. 2r. (Fig. 7) The miniature depicting the coat of arms (Fig. 8) is at the beginning of the text, in an oval cartouche. This is supplemented on the left by a decorative border of acanthus leaves, in which the shield is repeated. The miniature also contains the signature $D H$, like the one on the letters patent of János Pethő de Gerse (III) (Fig. 5), which is located above the military

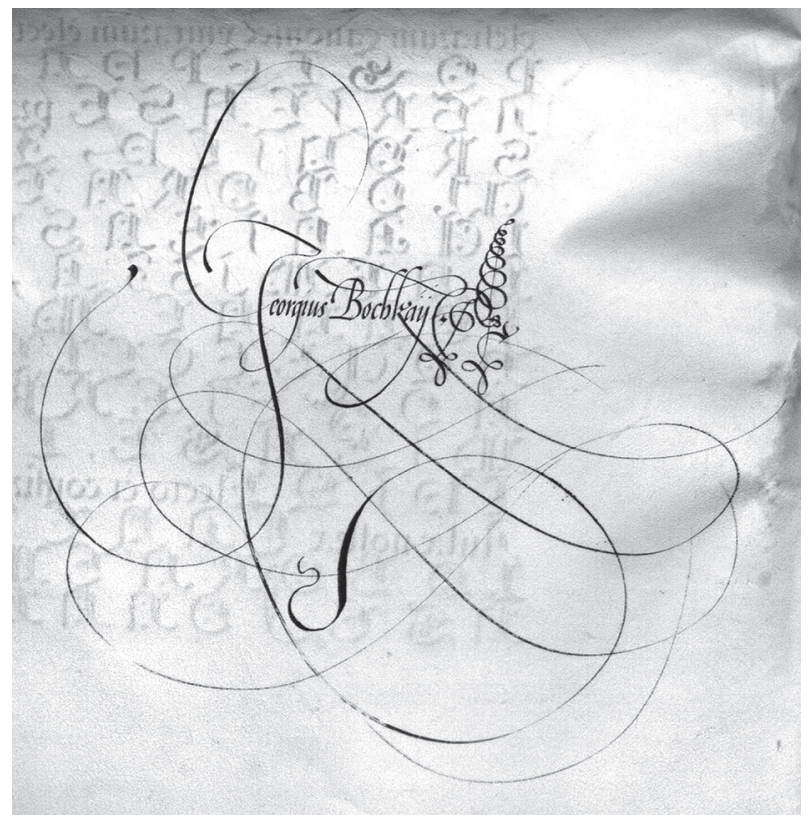

Fig. 10. Signature of George Bocskay on the letters patent of János Liszthy, 1573;

Esztergom, Primatial Archives, Acta Radicalia Cl. T, Nr. 168. fol. 4v, detail (photo by Esztergom, Primatial Archives, 2012)

trophies painted in the lower left-hand corner of the cartouche. The two works were probably produced by the same painter, who may have been Donat Hübschmann, as both feature the same decorative elements of strapwork, scrollwork ("Rollwerk"), putti, garlands of fruit and military trophies. The modelling of the figures depicted on the two charters, however, is as different as can be, which means that we must proceed with caution regarding whether or not they were made by the same hand. The cartouche contains the coat of arms of János Liszthy. Above this is the coat of arms of the granter, Maximilian I (II), with the imperial crown held by two putti. The lower section of the cartouche depicts military trophies and two weighty tomes, the latter probably referring to Liszthy's humanist activities.

The two-page frontispiece (fols. 2r-2v, Figs. 7, 9) was decorated with intricate calligraphy. Among the details that may be attributed to George Bocskay, the most striking element is once again the entrelac Neudörffer-style Fraktur. ${ }^{59}$ In comparison with the letters patent presented above, however, this letter form is used more prominently in this case, not only to emphasise the first line of the Latin text - in both the "M" and the "A" of "Maximilianus" - but also to begin every word on the page. The initials are in gold, and combined with German blackletters, which 
are written in gold in the first and third lines, and in blue in the second line. The composition is supplemented with an extraordinary variety of black arabesques, with the one beside the initial "D" also being gilded. The interlinear spacing is filled with horizontal and vertical ornaments, which also form the frame around the text. No two are the same shape, and the differences in form are further accentuated by varying the penwork with hatching or by filling in the surface.

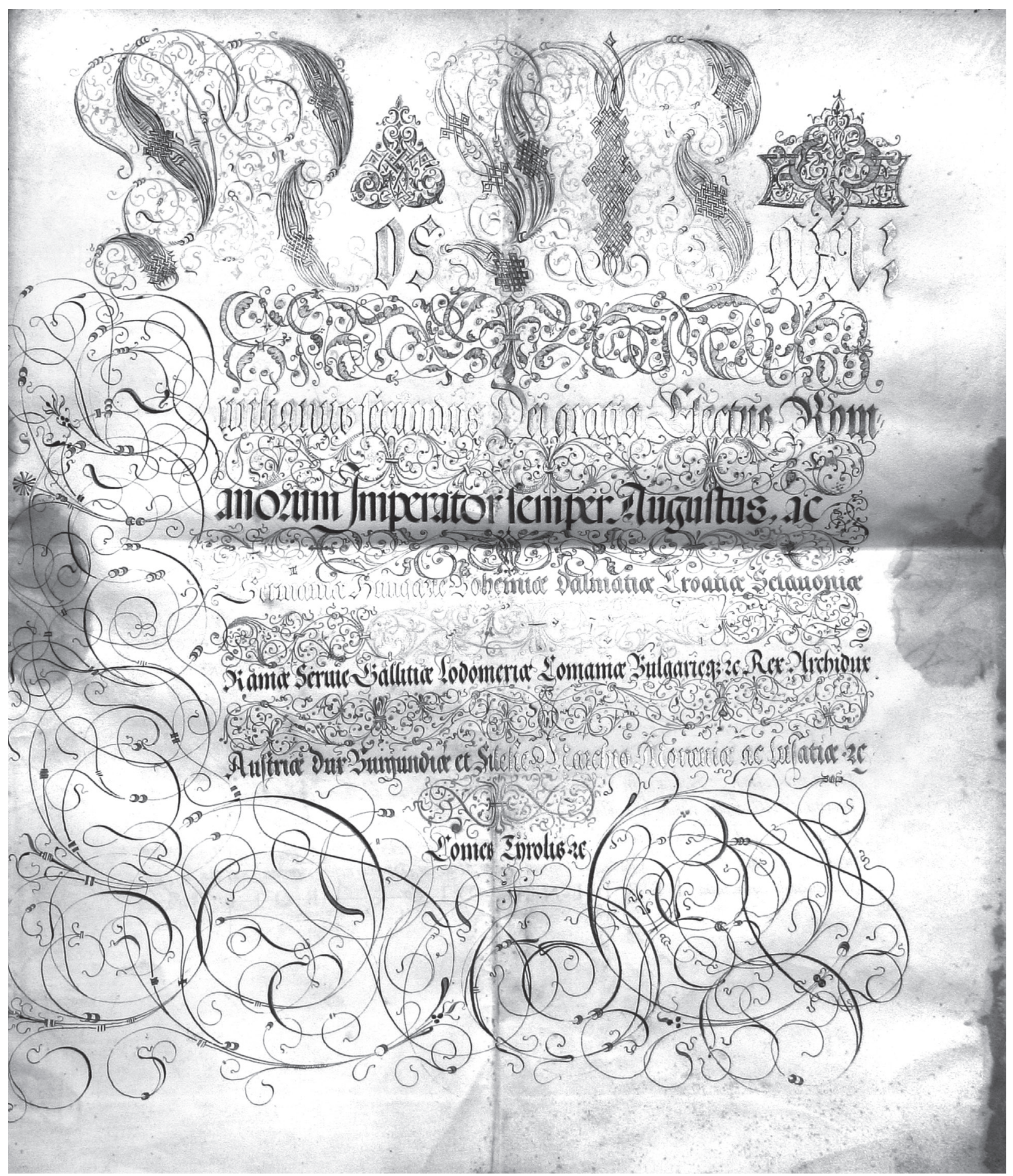

Fig. 11. George Bocskay: Frontispiece of the charter ratifying the marriage of Archduchess Barbara of Austria and Alfonso II d'Este, 1565; ÖStA HHStA Urkundenreihen Habsburg-Lothringische Familienurkunden, No. 1355. fol. 1r (photo by ÖStA, 2009) 
The titulary of Maximilian I (II) extends across to the verso of the folio (fol. 2v, Fig. 9). This can still be regarded as part of the calligraphic frontispiece, because the most complex letter forms and arabesques continue for two more lines. The closing element at the end of a line of gold blackletters with black initials is treated particularly decoratively, with the Roman capitals (antiqua) in gold being surrounded by black ornaments of an arabesque character. The remainder of the text is written

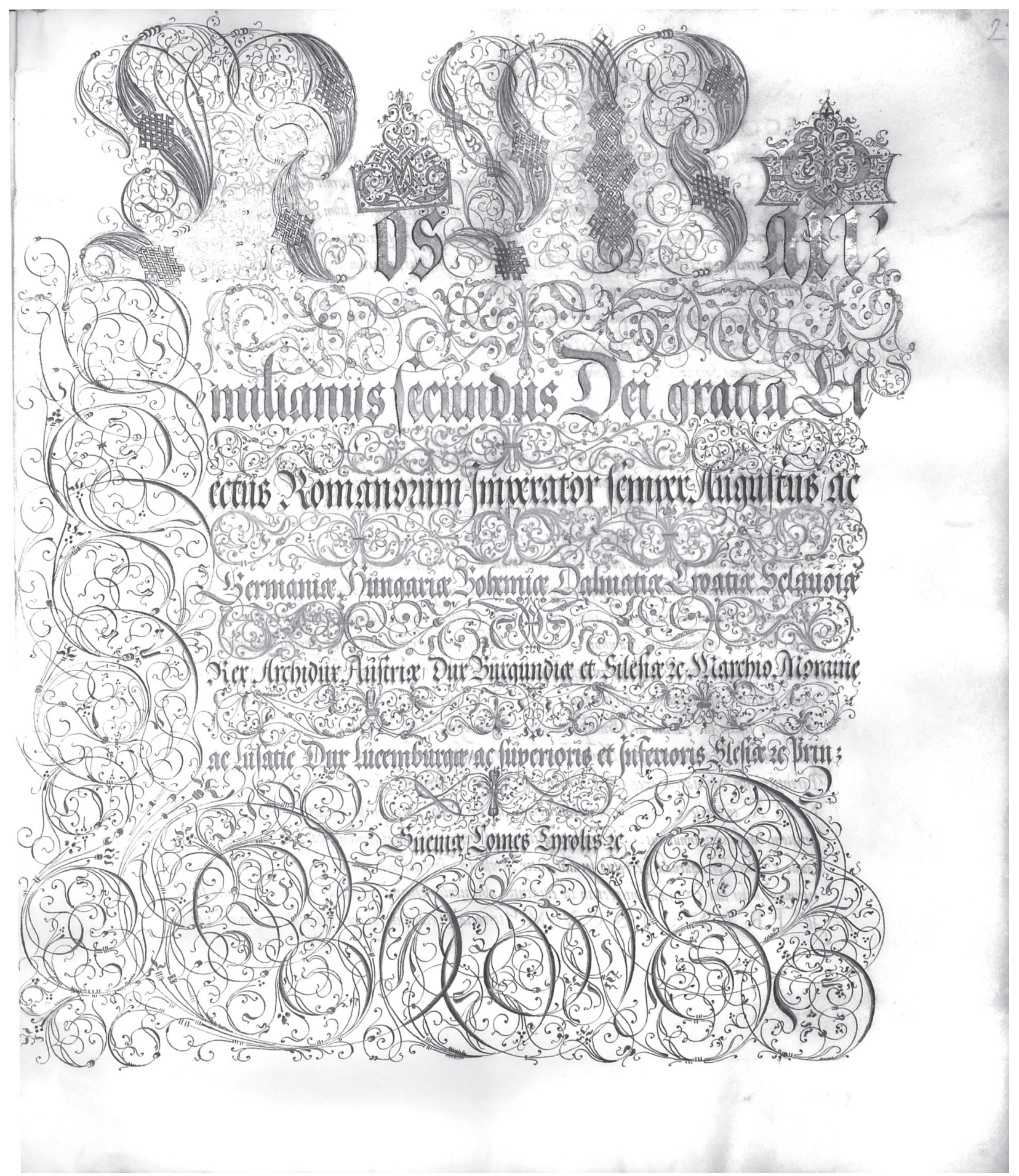

Fig. 12. George Bocskay: Frontispiece of the charter ratifying the marriage of Archduchess Joanna of Austria and Francesco Medici, 1565; Firenze, Archivio di Stato, Trattati internazionali, V. fol. 2r

(photo by Firenze, Archivio di Stato, 2007, su concessione del Ministero dei Beni e delle Attività Culturali del Turismo) 
in bollatica (Italian Gothic). In my view, Bocskay used letter form in deliberate reference to the formal precedent of the Oláh libellus (Fig. 1), whose running text was written in the same script. This is a calligraphic means of expressing the instrumental role played by Miklós Oláh in the advancement of János Liszthy's career at the Chancellery. The text in this charter continues until fol. $4 \mathrm{v}$, where the signature of the issuing King Maximilian I (II) can be found. Although Liszthy now headed the Chancellery, he could not countersign his own letters patent, just as Oláh had not countersigned his own charter when he had been the head. In the bottom right-hand corner, however, can be seen the signature of George Bocskay. (Fig. 10) I am of the opinion that the sophisticated stylisation of the name serves a dual function: not only is it the official mark of the court secretary, it is also the signature of the calligrapher who decorated the work.

\section{Charters Produced in the Service of Habsburg. Marriage Diplomacy}

The last two charters dealt with in this paper that can be attributed to George Bocskay (Figs. 11-12) are not letters patent but marriage ratification charters. It is my opinion that the "calligrapher to the ruler" received the commission to decorate these documents directly from Maximilian I (II). This honour marked a further step of recognition in the artist's career, for the task was one of great significance regarding the representation of the Habsburg dynasty abroad. Bocskay had already been entrusted with a task of similar prestige when he was ordered to make the inscriptions on the sepulchral monument of Emperor Maximilian I in Innsbruck, ${ }^{60}$ a project that was already largely underway by 1565 , the year in which the marriage ratification charters were decorated.

The marriage policy pursued by the Habsburg dynasty played a fundamental role in the family's acquisition of estates and in its diplomatic success abroad. Around the middle of the sixteenth century, seven of the ten grown-up daughters of Ferdinand I were married off to male members of different ruling families, four of which were in Italy. The last two Italian weddings, for which the marriage ratification charters in question were produced, took place within a short time of each other, at the end of 1565. Archduchess Barbara
(1539-1572) became the wife of Alfonso II d'Este (1533-1597, Duke of Ferrara: 1559-1597), while Archduchess Joanna (1547-1578) was married to Francesco Medici (1541-1587, Grand Duke of Tuscany: 1574-1587). ${ }^{61}$ These marriages were the result of many years of diplomatic negotiations. The Habsburg-d'Este marriage agreement came about in 1564, while the final decision to join Archduchess Joanna in matrimony to Francesco Medici was taken in January 1565. The latter marriage, which united the heir of Cosimo I Medici (Duke of Florence: 1537-1569, Grand Duke of Tuscany: 1569-1574) with the daughter of the recently deceased Emperor Ferdinand I and sister of the present Emperor Maximilian II, was of crucial importance to the Florentine family. The Medicis were already recognised by European ruling families as one of the longest standing noble dynasties, and this marriage would lead indirectly to them being granted the title of Grand Duke of Tuscany. ${ }^{62}$

To mark the two marriages, Emperor Maximilian II and his two brothers, Archdukes Ferdinand (1529-1595) and Charles (1540-1590), issued charters ratifying the marriage contracts ${ }^{63}$ that had already been concluded with the two Italian families. Both charters were issued at the same time and place, in Vienna on 1 November 1565. ${ }^{64}$ The Habsburg-d'Este charter survives in the archives in Vienna ${ }^{65}$ (Fig. 11), while the Habsburg-Medici charter is in the archives in Florence. ${ }^{66}$ (Fig. 12) This suggests that each of the charters was originally produced in two copies, although only one of each pair is now known. There are striking similarities between the calligraphic decorations on the two charters, even though they were issued for two separate events. This is probably due to the fact that in Vienna in 1565, preparations for both Italian marriages were carried out simultaneously; the dowries (clothes, jewellery, etc.), for example, were put together at the same time. ${ }^{67}$ Bocskay must therefore have been commissioned to decorate all four of the charters at the same time. One copy of each ratification charter would then have been kept in Vienna, while the other copy would have been taken by the Habsburg archduchesses when they left for Ferrara and Florence. The latter, as the official written documents of the marriages, would subsequently have been formally presented to the other families. 


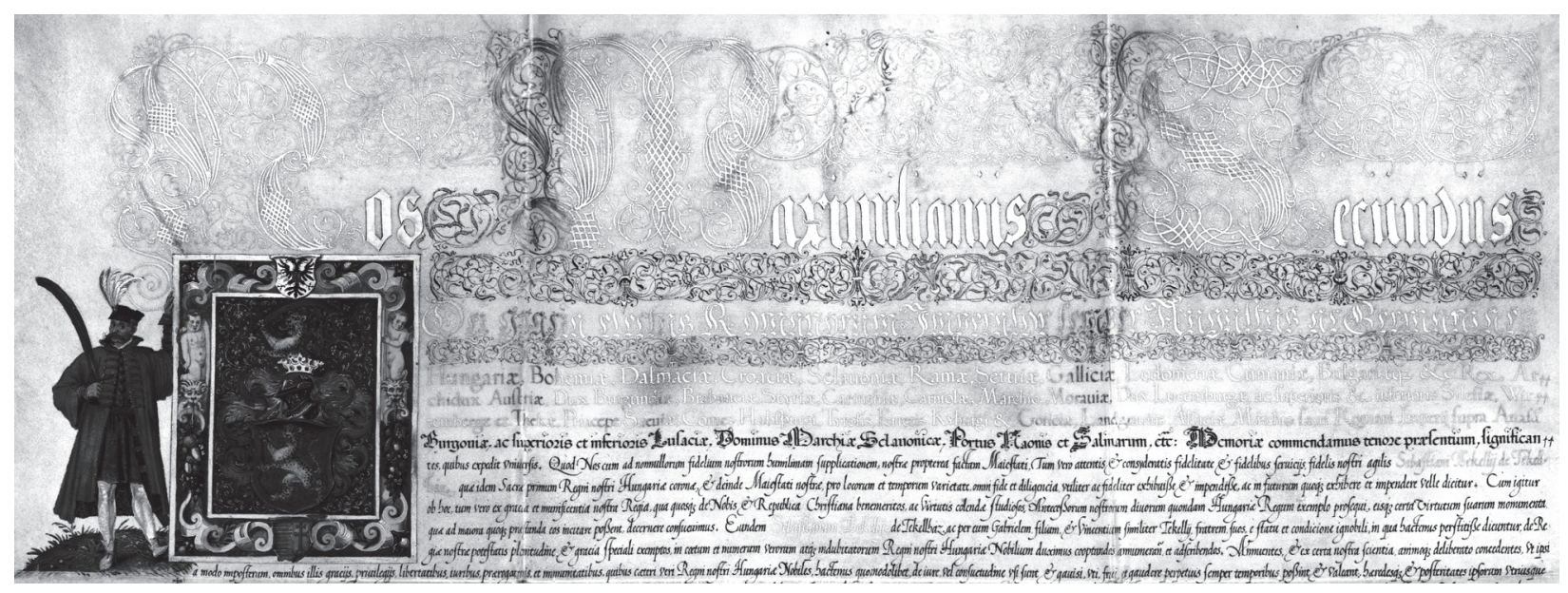

Fig. 13. George Bocskay: Frontispiece of the letters patent of Sebestyén Thököly, Bratislava, 27 October 1572; MNL OL, E 148, Fasc. 132. No 17, detail (photo by MNL OL, 2008)

The Habsburgs did their best to economise as much as possible, as evinced by the fact that Barbara and Joanna embarked for Italy as part of a joint entourage. They left Innsbruck on 14 November 1565, and proceeded together as far as Trento, where they parted company, meeting up again in Mantua on 30 November. From here, the two brides-to-be and their retinues continued separately, one to Ferrara, the other to Florence. $^{68}$

The wedding in Ferrara was held on 5 December 1565 . The accompanying festival closed with a costumed tournament held in one of the palace gardens, with the title Il tempio d'amore. The work proclaimed the power of virtuous love, and was probably written by the great Torquato Tasso, who was serving in the Court of Ferrara at the time. ${ }^{69}$ The copy - at present still unknown - of the richly decorated ratification charter (Fig. 11) was probably also presented to the d'Este family during the celebrations. The increasingly close relationship between the two dynasties is demonstrated by the fact that the costumed tournament held in Bratislava in 1572 to commemorate the coronation of Archduke Rudolf as King of Hungary (King Rudolf I: 1572-1608, Rudolf II, Holy Roman Emperor: 1576-1612) was deeply influenced by Il tempio d'amore. ${ }^{70}$

Joanna meanwhile, accompanied by her entourage, was making her way towards Florence, where she made her solemn entry on 16 December $1565 .^{71}$ The concept for the wedding festival and the specially built ephemeral edifices was devised by Vincenzo Borghini, while the constructions and artworks were made by Giorgio
Vasari and his workshop. ${ }^{72}$ No less than eleven temporary triumphal arches were raised along the route of the procession, while the more permanent fixtures made for this occasion included the Neptune Fountain on the Piazza della Signoria, sculpted by Bartolommeo Ammannati. ${ }^{73}$ The final station of the entry procession was the Palazzo Vecchio, where Joanna of Austria was welcomed on the steps by her groom, Francesco Medici; the couple then proceeded into the palace through Michelozzo's courtyard, newly refurbished for this occasion. ${ }^{74}$ Giorgio Vasari and members of his workshop decorated the courtyard in a magnificent Late Mannerist style; the columns were finished with stucco "alla Romana," the vaults were given a variety of grotesque decorations, while the walls were painted with medallions and vedute also framed within grotesque elements. ${ }^{75}$ The medallions were imitations of ancient coins, and exalted the deeds of the groom's father, Cosimo I Medici. The vedute, meanwhile, showed images from the bride's dynastic lands, depicting seventeen cities (Vienna, Innsbruck, Prague, Linz, Bratislava and Graz, among others) under the control of the Austrian branch of the Habsburgs. Joanna's reception was celebrated in the Sala Grande, the largest room in the palace, whose ceiling frescos - also by Vasari and his workshop -, with the apotheosis of Cosimo I Medici at its centre, had only recently been completed. ${ }^{76}$ The wedding ceremony was held two days later in Florence Cathedral. It was probably on the next day ${ }^{77}$ that the Florentine copy (Fig. 12) of the ornate ratification charter was presented to the Medici 
family. The festivities - costumed processions, dramatic performances, tournaments, balls and banquets - lasted from Christmas 1565 all the way until Shrovetide $1566 .^{78}$

Below follows a description of the two marriage ratification charters. Both are parchment manuscripts in booklet form (libelli), measuring the same size (approximately $38 \times 32.5 \mathrm{~cm})$. The charter currently in Vienna, ratifying the d'Este marriage (Fig. 11), consists of two bifolia, with a truncated fourth folio, which was subsequently cut off at the sewing. The text occupies five pages, from the recto of the frontispiece (fol. 1r) until fol. 3r, which bears the signature of Emperor Maximilian II, who issued the document, and those of the two archdukes, Ferdinand and Charles. The manuscript probably once consisted of three bifolia, like its counterpart in Florence, but the blank first folio and the three wax seals are now missing. The charter in Florence today (Fig. 12) is somewhat longer, consisting of three bifolia, the first being blank. The text covers six pages, from the recto of the frontispiece (fol. 2r) until fol. $4 v$. Furthermore, it still bears the wax seals of Maximilian II, Ferdinand and Charles.

There is only calligraphic decoration on the charters (Figs. 11-12), which is almost entirely identical in both cases. The decoration on both of them can be easily attributed to George Bocskay, except for the arabesques placed next to the initials in the upper section of both frontispieces; these arabesques are less expertly drawn than the rest of the ornaments, which indicates that they were probably executed by a different hand. The first line of the Latin text that begins "Nos Maximilianus" was decorated with the initials "N" and "M" in Neudörffer-style Fraktur" in gold. The text continues in blackletter, written on alternate lines in gold or black. The composition is supplemented with extremely elaborate interlinear arabesques and foliate ornaments, and virtuoso marginal flourishes. In my opinion, the letter forms employed on the frontispiece were chosen not only with decorative requirements in mind. These distinctly German hands were intended to represent the Habsburg dynasty in an Italian environment. In this context, a contrast can be provided by the far more simply executed charter issued by the Medicis, ${ }^{80}$ in which Cosimo I Medici and his heir, Francesco, recognised the latter's marriage to the Habsburg archduchess; this document was written in its entirety in elegant antiqua. The text on the two Bocskay-decorated marriage charters continues, from the verso of the frontispiece, in italic script. The names are picked out from the black text using expertly formed Roman capitals in gold. No additional ornamentation is to be found on the further pages. The high quality of the running texts on both documents indicates that they were also executed by Bocskay himself.

The calligraphic composition of the two frontispieces bears comparison with a number of other works by Bocskay. As we have already seen, the highly decorative entrelac, Neudörfferstyle Fraktur capitals play a key role on all the letters patent in booklet form that can be attributed to the calligrapher. (Figs. 1, 4, 6, 7) It should also be noted that the largest group of letters patent on a single folio issued at the Hungarian Court Chancellery, which can also be attributed to Bocskay, consists of manuscripts decorated with the same script. (Fig. 13) Neudörffer initials also appear regularly in the three known writing model books produced by the calligrapher. ${ }^{81}$ The second characteristic of the compositions is the way in which the texts are richly embellished with a variety of ornaments. The interlinear spacing is filled with arabesques and foliate ornaments, which are combined with extravagant marginal flourishes. Such decorative elements are also coloured gold, or black with gold dots, in line with the script itself. Regularly alternating the two types of colouring, both within the individual interlinear ornament units, and together with the other interlinear ornament units, results in symmetrical formations. Similar ornaments frequently appear on letters patent attributable to Bocskay, especially on works whose main decorative element is also Neudörffer-style Fraktur in gold. (Figs. 6, 13) Similarly refined marginal flourishes in black and in gold can also be found in Bocskay's writing model books. ${ }^{82}$ In his manuscript of 1571-73, meanwhile, multiple use is also made of the regular interplay of black and gold interlinear arabesques. ${ }^{83}$

In summary, it can be said that letters patent and charters embellished with elaborate calligraphy - alongside his writing model books and his sepulchral inscriptions - constitute another important subdivision of the ouvre of George Bocskay. There can be no stronger evidence of 
the high esteem in which his calligraphic artistry was held by the Viennese court than the fact that not only members of the Hungarian ecclesiasti- cal and lay elites, but even the ruler himself, commissioned Bocskay to decorate these exceptionally important official documents.

\section{ABBREVIATIONS}

\section{Archives, manuscripts}

MNL OL

Ms. 1561-62

Ms. 1562

Ms. $1571-73$

ÖStA AVA FHKA HKA

ÖStA HHStA
Magyar Nemzeti Levéltár Országos Levéltára / National Archives of Hungary, Budapest

Writing model book by George Bocskay (illuminated by Joris Hoefnagel before 1596), The J. Paul Getty Museum. Los Angeles, Ms. 20.

Writing model book by George Bocskay, Österreichische Nationalbibliothek, Wien, Sammlung von Handschriften und alten Drucken, Cod. ser. n. 2664

Writing model book by George Bocskay (illuminated by Joris Hoefnagel in 1591-94), Kunsthistorisches Museum, Wien, Kunstkammer, Inv.-Nr. KK 975.

Osterreichisches Staatsarchiv, Wien, Allgemeines Verwaltungsarchiv, Finanz- und Hofkammerarchiv, Hofkammerarchiv

Österreichisches Staatsarchiv, Wien, Haus-, Hof- und Staatsarchiv

\section{BIBLOGRAPHY}

Almási 2009 - Almási, Gábor: The Uses of Humanism. Johannes Sambucus (1531-1584), Andreas Dudith (15331589), and the Republic of Letters in East Central Europe, Leiden 2009. (Brill's Studies in Intellectual History, 185)

Amphiareo 1554 - Amphiareo, Vespasiano: Uno novo modo d'insegnar a scrivere et formar lettere di piu sorte („Opera”), Vinegia 1554. (facsimile edition: TschichoLD 1975)

ARRIGHI 1523 - ARRIGHI (VICENTINO), Ludovico degli: La Operina. Il modo de temperare le Penne, Roma 1523. (facsimile edition: OGG 1953, 3-62)

ÁLDÁsY 1923 - ÁLDÁsY, Antal: Címertan [Heraldry], Budapest 1923.

Beke 1995 - Beke, Margit: A Prímási Levéltár nemesi és címeres emlékei [Heraldic and armorial artefacts in the Primatial Archives]. Esztergom 1995.

BEYER 2008 - BEYER, Andreas: Die Szene der Fürsten. Arcimboldos Kostüme und Entwürfe für höfische Feste und Turniere, in Arcimboldo 1526-1593, ed. Ferino-PAgDEN. Sylvia (Exh. Cat. Kunsthistorisches Museum, Wien - Musée du Luxembourg. Paris), Wien-Ostfildern-Milano 2008. 243-247.

BOEHEIM 1888 - Urkunden und Regesten aus der K. K. Hofbibliothek [1], ed. BоEHEIM, Wendelin, Jahrbuch des Kunsthistorischen Sammlungen des Allerhöchsten Kaiserhauses VII. 1888. XCI-CCGXIII. (http://digi.ub.uniheidelberg.de/diglit/jbksak1888a/0401? sid=f8e009473 87b269060a8ab44aa3b2938)

Carsillo 2006 - Carsillo, Laura: Gli apparati decorativi del 1565, tra l'effimero e il definitive, in Palazzo Vecchio. Officina di opere e di ingegni, ed. FrancinI, Carlo, n.p. 2006. 246-249.

Casamassima 1966 - Casamassima, Emmanuelle: Trattati di scrittura del Cinquecento Italiano, Milano 1966. (Documenti sulle arti del libro, V)

Chmelarz 1896 - ChMELARZ, Eduard: Georg und Jakob Hoefnagel, Jahrbuch der Kunsthistorischen Sammlungen des Allerhöchsten Kaiserhauses XVII. 1896. 275-290. (http://digi.ub.uni-heidelberg.de/diglit/ibksak1896/0294 ?sid=f8e00947387b269060a8ab44aa3b2938)

CinI 1568 - [CINI, Giovanni Battista: La descrizione dell'apparato per le nozze del Principe Francesco de Medici [1568], in Le opere di Giorgo Vasari. Tomo VIII. Scitti minori, ed. MiLanesI, Gaetano, Firenze 1882. $517-622$.

Csízi 2012 - Csízi, István: A gersei Pethő család címerének változásai az évszázadok folyamán [Developments in the coat of arms of the Pethő de Gerse family throughout the centuries], Turul 85. 2012. 46-55.

DaCosta Kaufmann 1978 - DaCosta Kaufmann, Thomas Variations on the Imperial Theme. Studies in Ceremonial, Art, and Collecting in the Age of Maximilian II and Rudolf II, New York - London 1978. (A Garland series. Outstanding dissertations in the fine arts)

Diemer 2004 - Diemer, Dorothea: Kaiser Maximilians Kenotaph in der Innsbrucker Hofkirche - seine Vorgeschichte, seine Entstehung und seine Künstler, in DIEMER. Dorothea - Haidacher, Christoph: Maximilian I. Der Kenothaph in der Hofkirche zu Innsbruck, mit Beiträgen von BADERWieslauer, Ursula und Wieslauer, Karl, SchlöGL, Johannes Stephan, ANTRETTER, Sigrid und PICHLER, Birgit, NiEDERBACHER, Josef, Innsbruck-Wien 2004. 32-64.

DoEde 1958a - DoEDE, Werner: Bibliographie deutscher Schreibmeisterbücher von Neudörffer bis 1800, Hamburg 1958.

DOEDE $1958 b$ - DoEDE, Werner: Schön schreiben, eine Kunst. Johann Neudörffer und seine Schule im 16. und 17. Jahrhundert, München 1958

Exh. Cat. Bratislava 2009 - Renesancia. Dejiny slovenského výtvarného umenia, ed. LuDIKová, Zuzana Slovenská národná galéria, Bratislava), Bratislava 2009.

Exh. Cat. Budapest 1994 - Pannonia Regia. Müvészet a Dunántúlon 1000-1541 [Pannonia Regia. Art in Transdanubia 1000-1541], eds. MIKó, Árpád - TAKács, Imre (Magyar Nemzeti Galéria [Hungarian National Gallery], Budapest), Budapest 1994. (A Magyar Nemzeti Galéria kiadványai [Publicatons of the Hungarian National Gallery], 1994/3)

Exh. Cat. Budapest 2008a - Mátyás király öröksége. Késő reneszánsz müvészet Magyarországon (16-17. század) [The legacy of King Matthias. Late Renaissance art in Hungary. $16^{\text {th }}-17^{\text {th }}$ centuries], Vol. I, eds. MiKó, Árpád - VERő, Mária (Magyar Nemzeti Galéria [Hungarian National Gallery], Budapest), Budapest 2008. (A Magyar Nemzeti Galéria kiadványai [Publicatons of the Hungarian National Gallery], 2008/3)

Exh. Cat. Budapest $2008 \mathrm{~b}$ - The Splendour of the Medici. Art and Life in Renaissance Florence, eds. BIETTI, Monica - Giusti, Annamaria - Tátrai, Vilmos (Szépművészeti Múzeum [Museum of Fine Arts], Budapest), Budapest 2008.

Exh. Cat. Budapest-Bratislava 2005 - Mary of Hungary. The Queen and Her Court 1521-1531, eds. RÉTHELYI, Orsolya 
- F. Romhányi, Beatrix - SPEKNER, Enikő - VÉgh, András (Budapesti Történeti Múzeum [Budapest History Museum] - Slovenská národná galéria, Bratislava), Budapest 2005.

Exh. Cat. Essen-Vienna 1988 - Prag um 1600. Kunst und Kultur am Hofe Kaiser Rudolfs II, Vol. II. (Kulturstiftung Ruhr, Essen - Kunsthistorisches Museum, Wien), WienFreren 1988.

Exh. Cat. Innsbruck 2010 - Nozze italiane. Österreichische Erzherzoginnen im Italien des 16. Jahrhunderts, ed. HAAG, Sabine (Kunsthistorisches Museum Schloss Ambras, Innsbruck), Wien 2010.

Exh. Cat. Schallaburg 1982 - Schallaburg '82. Matthias Corvinus und die Renaissance in Ungarn, eds. STANGLER, Gottfried - Csáky, Moritz - Perger, Richard - JüNGER, Andrea (Schloss Schallaburg), Wien 1982. (Katalog des Niederösterreichischen Landesmuseums, N. F. 118)

Exh. Cat. Vienna 2001 - Kaiser und König. Eine historische Reise. Österreich und Ungarn 1526-1918. Ausstellung. im Prunksaal der Österreichischen Nationalbibliothek, 8 . März-1. Mai 2001, eds. FAZEKas, István - ÚJváry, Gábor, Wien 2001.

Exh. Cat. Vienna 2003 - Kaiser Ferdinand I. 1503-1564. Das Werden der Habsburgermonarchie, ed. SEIPEL, Wilfried (Kunsthistorisches Museum, Wien), Wien-Milano 2003.

FAZEKAS 2002 - FAZEKAS, István: A Magyar Udvari Kancellária leltára 1577-ből [The inventory of the Hungarian Court Chancellery from 1577]. Fons 9. 2002. (Tanulmányok a 60 éves Gecsényi Lajos tiszteletére [Essays written to commemorate the sixtieth birthday of Lajos Gecsényi]), 227-247. (http://www.fonsfolyoirat.hu/images/ fonsanyagok/Fons/fons/2002.pdf)

FAZEKAS 2003 - FAZEKAS, István: Ungarns König Ferdinand I, in Exh. Cat. Vienna 2003, 117-129.

FAZEKAs 2005a - FAZEKAS, István: Miklós Oláh, Secretary to Queen Mary of Hungary, 1526-1539, in Exh. Cat. Budapest-Bratislava 2005, 41-47.

FAZEKAS 2005b - FAZEKAS, István: Oláh Miklós esztergomi érsek udvara (1553-1568) [The court of Miklós Oláh, Archbishop of Esztergom (1553-1568)], in Idővel paloták... Magyar udvari kultúra a 16-17. században [Palaces over time... Hungarian court culture in the 16th17th centuries], eds. G. ETÉNYI, Nóra - HorN, Ildikó, Budapest 2005. 343-360.

FAZEKAS 2005c - FAZEKAS, István: Miklós Oláhs Reformbemühungen in der Erzdiözese Gran zwischen 1563 und 1568. in Kaiser Ferdinand I. Ein mitteleuropäischer Herrscher, eds. Fuchs, Martina - OborNI, Teréz - UJváRy, Gábor, Münster 2005. 163-178.

FAZEKAS 2006 - FAZEKAS, István: Adalékok az ifjú Bocskai István bécsi udvarban eltöltött éveihez [Contributions to our knowledge of the years spent by the young István Bocskai at the Viennese Court], Studia Caroliensia 7. 2006. 73-85.

FAZEKAS 2011 - FAZEKAS, István: Humanisten und Juristen. Das Personal der Ungarischen Hofkanzlei in der frühen Neuzeit (1526-1690), in Institutions of Legal History with Special Regard to Legal Culture and History, eds. Béli, Gábor - Duchonoví, Diana - Fundarková, Anna - Kajtár, István - Peres, Zsuzsanna, Pécs-Bratislava 2011. 321-331.

FAZEKAS 2012 - FAZEKAS, István: Die Geschichte der Ungarischen Hofkanzlei (1527-1687) und der Siebenbürgischen Hofkanzlei (1695-1867), in Das ungarische Botschaftsgebäude in Wien. Studien zur Amts- und Kunstgeschichte, ed. UJVÁRY, Gábor, Wien 2012. 49-65.

FAZEKAs 2013 - FAZEKas, István: Die Ungarische Hofkanzlei und der Habsburgische Hof (1527-1690), in FuNDÁRKOVÁ-FAZEKAS 2013, 103-124.

Fiorani 2007 - Fiorani, Francesca: Cycles of Painted Maps in the Renaissance, in WOODWARD 2007, Part 1, 804-830. (http://www.press.uchicago.edu/books/HOC/HOC_V3_ Pt1/HOC_VOLUME3_Part1_chapter32.pdf

FugGER 1553 - FugGER, Wolfgang: Schreibbüchlein. Ein nützlich und wolgegrundt Formular Manncherley schöner shriefften, Nürnberg 1553. (facsimile edition: ed. FuNKE, Fritz. Leipzig 1958)

FunDÁRKOVÁ-FAZEKAS 2013 - Die weltliche und kirchliche Elite aus dem Königreich Böhmen und Königreich Ungarn am Wiener Kaiserhof im 16.-17. Jahrhundert, eds. FunDÁRKOVÁ, Anna - FAZEKAS, István et al., Wien 2013. (Publikationen der ungarischen Geschichtsforschung in Wien, 8)

Galavics 1995 - Galavics, Géza: The Hungarian Royal Court and Late Renaissance Art, Hungarian Studies 10. 1995 307-332. (http://epa.oszk.hu/01400/01462/00017/pdf/ 307-332.pdf

Galavics 2001 - Galavics, Géza: Martino Rota: Bildnis des Zacharias Mossóczy (1577) und das humanistische Porträt in Ungarn, Acta Historiae Artium XLII. 2001. 65-81.

GROHS 1988 - GROHS, Brigitte: Italienische Hochzeiten. Die Vermählung der Erzherzoginnen Barbara und Johanna von Habsburg im Jahre 1565. Mitteilungen des Instituts für Österreichische Geschichtsforschung 96. 1988. 331-381.

GULYÁs 2013a - GULYÁs, Borbála: Egy elfeledett armális a 16. század második feléből, Gersei Pethő János címerbővítő oklevele (1572) [A forgotten grant of arms letters patent from the second half of the 16th century. The letters patent on the new additions to the coat of arms of János Pethő de Gerse (1572)], Ars Hungarica XXXIX. 2013. No. 1. (Liber decorum. Wehli Tünde köszöntése I. [Essays written in honour of Tünde Wehli]), 61-66. (http:// mi.btk.mta.hu/hu/ars-hungarica)

GulYás 2013b - GuLYÁs, Borbála: Bocskay György kalligráfus oklevelei a Habsburg házassági diplomácia szolgálatában The calligraphic charters produced by George Bocskay in the service of Habsburg marriage diplomacy], Ars Hungarica XXXIX. 2013. Suppl. (Tanulmányok Kelényi György tiszteletére [Essays written in honour of György Kelényi]), 54-58. (http://mi.btk.mta.hu/hu/ars-hungarica)

GuLYÁs 2014 - GuLYás, Borbála: ..gegen den Bluedthunden und Erbfeindt der Christenhait". Thematisierung der Türkengefahr in Wort und Bild an den höfischen Festen der Habsburger in der zweiten Hälfte des 16. Jahrhunderts, in Türkenkriege und Adelskultur in Ostmit teleuropa vom 16. bis zum 18. Jahrhundert, eds. BORN. Robert - JagODZINSKI, Sabine, Ostfildern 2014. (Studia Jagellonica Lipsiensia, 14), 217-236.

GuLYÁs 2015 - GuLYÁs, Borbála: Inscriptions "all'antica" of the Sepulchral Monument of Emperor Maximilian I in Innsbruck by the calligrapher George Bocskay, Frühneuzeit-Info 26. 2015. 219-227.

GulYás 2016 - GulYás. Borbála: "Achtet Casten, darinnen allerleÿ Büecher". Prints and Manuscripts in the Kunstkammer of Ferdinand of Tyrol, in: Collecting Prints and Drawings, ed. GÁLDY, M. Andrea, Newcastle upon Tyne 2016. (in preparation at time of going to print)

Gulyás 2017 - Gulyás, Borbála: The Fight Against the Ot tomans in Hungary and the Court Festivals of the Habsburgs in the Sixteenth Century, in Identity and Culture in Ottoman Hungary, eds. Fodor, Pál - Ács. Pál. Berlin 2017. (Studien zur Sprache, Geschichte und Kultur der Türkvölker)

Gyulai 2012 - Gyulai, Éva: Von Sachen gros, von Angsicht klein - Zsámboky János verse Pozsonyról a Habsburg Miksa koronázásáról készült metszeten, 1563/1566 [Verses by János Zsámboky on Bratislava, on the print commemorating the coronation of Habsburg Maximilian], Publicationes Universitatis Miskolcinensis, Sectio Philosophica 17. 2012. 125-151. (http://www.matarka. hu/koz/ISSN_1219-5448/tomus_17_fas_1_2012/ ISSN_1219-5448_tomus_17_fas_1_2012_125-151.pdf)

HENDRIX 1988 - HENDRIX. Lee: An Introduction to Hoefnagel and Bocskay's Model Book of Calligraphy in the J. Paul Getty Museum, in Prag um 1600. Beiträge zur Kunst und Kultur am Hofe Rudolfs II. Symposion, Prag, Juni 1987, Freren 1988. 110-117.

HeNDRIX 1992 - HeNDRIX, Lee: The Writing Model Book, in HENDRIX - VIGNAU-WILBERG 1992. 31-54. 
Hendrix - Vignau-Wilberg 1992 - Hendrix, Lee - VignauWILBERG, Thea: Mira calligraphiae monumenta. A Sixteenth-Century Calligraphic Manuscript. Inscribed by George Bocskay and Illuminated by Joris Hoefnagel, Malibu [1992].

JAKÓ 1968 - JAKÓ, Zsigmond: A művészetpártoló. Oláh Miklós emlékére Miklós Oláh - a patron of the arts], Korunk 27. 1968. No. 2, 200-204. (http:// epa.oszk.hu/00400/00458/00374/pdf/Korunk_ EPA00458_1968_02_200-204.pdf)

JoHnson 1950 - A Catalogue of Italian Writing-Books of the Sixteenth Century, ed. Johnson, A. F., Signature N. S. 10. $1950.22-48$

KAPOSsY 1956 - KAPOSsY, János: Művészettörténeti regeszták a királyi határozatokból és rendeletekből. XVI. század [Art historical regestae from royal decrees and edicts. $16^{\text {th }}$ century][1-3.7, Müvészettörténeti Értesítő 5. 1956. 47-53. 190-197. 318-330.

KAPR 1956 - KAPR, Albert: Johann Neudörffer d. Ä. der große Schreibmeister der deutschen Renaissance, Leipzig 1956.

KatRitzky 1996 - KatRiTzKy, M. A.: The Florentine Entrata of Joanna of Austria and Other Entrate Described in a German Diary, Journal of the Warburg and Courtauld Institutes 59. 1996. 148-173.

KIss 2004 - KISs, Farkas Gábor: A Ragyogó Mágus, avagy a Balassák az udvari ünnepélyeken [Il Mago rilucente, or the Balassi family at courtly festivities], in: Balassi Bálint és a reneszánsz kultúra. Fiatal kutatók Balassi-konferenciája [Bálint Balassi and culture of the Renaissance. Conference on Balassi of young researchers], ed. KIss, Farkas Gábor, Budapest 2004. (Traditio Renovata, 1), 89-119. (http://mek.oszk.hu/04500/04529/04529.pdf)

Kovács 1969 - Kovács, András: Diplomele de înnobilare şi iconografia lui Nicolaus Olahus, Revista Muzeelor 6. 1969. No. 2. 101-110.

Kovács 1994 - Kovács, András: Oláh Miklós címereslevelei [The letters patent of Miklós Oláh]. Korunk 3/5. 1994. No. 4, 103-108. (http://kovacs.adatbank.transindex.ro/ belso.php? $\mathrm{k}=64 \& \mathrm{p}=5135)$

KóTA 1997 - KóTA, Péter: A címereslevél ára [The price of a letters patent], in Mágnások, birtokosok, címereslevelesek [Magnates, landowners and the armorial nobility]. eds. ÓDOR, Imre - PÁLMÁNY, Béla - TAKács, Péter, Debrecen 1997. (Rendi társadalom - polgári társadalom [Feudal society - civil society], 9), 149-156. (http://hajnalkor.hu/ files/rendi_es_polgari_009.pdf)

LiETZMANN 1992 - LIETZManN, Hilda: Quellen zur ungarischen Krönung Rudolfs II. im Jahre 1572, Mitteilungen des Österreichischen Staatsarchivs 42. 1992. 63-101.

LINKE 2004 - LINKE, Oliver: Das kalligrafische Werk Johann Neudörffers d. Ä. (Magisterarbeit), Augsburg 2004.

LINKE-SAUER 2007 - LINKE, Oliver - SAUER, Christine: Zierlich schreiben. Der Schreibmeister Johann Neudörffer d. Ä. und seine Nachfolger in Nürnberg, Nürnberg 2007. (Beiträge zur Geschichte und Kultur der Stadt Nürnberg, 25)

LuDIKOVÁ 2009 - LuDIKOVÁ, Zuzana: Zsámboky János röplapja Miksa magyar királlyá koronázásáról [Johannes Sambucus's broadsheet about the coronation of Maximilian as King of Hungary], Századok 143. 2009. 975-980.

Meldini 1566 - MelLini, Domenico: Descrizione dell'entrata... Firenze 1566.

MIKó 2005 - MIKó, Árpád: Illuminated Grants of Arms of King Louis II. Art Historical Questions Linked to a Specific Form of Heraldic Representation in the Hungary of the Late Jagiellon Period, in Exh. Cat. Budapest-Bratislava 2005, 81-95.

Mıкó 2013 - Mıкó, Árpád: Pietro Ferrabosco számadása a Miksa magyar királlyá koronázására épített pozsonyi diadalkapukról (1563) [Pietro Ferrabosco's bill of costs concerning the triumphal arches erected for the coronation of Maximilian I of Hungary], Müvészettörténeti Értesítö 62. 2013. 323-328.
Nagler 1964 - Nagler, A. M.: Theatre Festivals of the Medici. 1539-1637, New Haven - London 1964.

NEUDÖRFFER c.1550 - NEUDÖRFFER, Johannes d. Ä.: »FrakturInitial-Buch«, Nürnberg c.1550. (facsimile edition: LINKE 2004. 130-164.

Ny. Straub 2000 - Ny. Straub, Éva: Címereslevelek jegyzéke. Második, javitott, bővitett kiadás [Registry of letters patent granting armorial bearings. Second, amended and expanded edition], Budapest 2000. (A Magyar Országos Levéltár segédletei [Auxiliary publications of the Hungarian National Archives], 7)

OgG 1953 - Three Classics of Italian Calligraphy. An una bridged reissue of the writing books of Arrighi Tagliente Palatino, ed. OGG, Oscar, New York 1953.

Palatino 1561 - Palatino, Giovanbattista: Libro nuovo, Roma 1561. (facsimile edition: OGG 1953, 123-248.)

PÁlfFy 2002 - PÁLFFy, Géza: Medien der Integration des ungarischen Adels in Wien im 16. und 17. Jahrhundert, Collegium Hungaricum-Studien Wien 1. 2002. 61-98. (http://www.academia.edu/6492443/Medien_der_Integration_des_ungarischen_Adels_in_Wien_im_16. und_17. Jahrhundert. In_Collegium_Hungaricum-Studien_Wien_1._2002_61_98)

PÁLFFY 2009 - PÁLFFY, Géza: The Kingdom of Hungary and the Habsburg Monarchy in the Sixteenth Century, New York 2009. (East European Monographs Bd. DCCXXXV, CHSP Hungarian Studies Series. 18)

PÁlffy 2013 - PálfFy, Géza: Der Adel aus den ungarischen Ländern am Kaiserhof 1526-1612, in FunDÁRKOVÁFAZEKAS 2013. 37-76.

Perger 1994 - Perger, Richard: Das Palais Esterházy in der Wallnerstraße zu Wien, Wien 1994. (Forschungen und Beiträge zur Wiener Stadtgeschichte, 27)

Pfaffenbichler 1992 - Pfaffenbichler, Matthias: Das Turnier als Instrument der Habsburgischen Politik, Waffen- und Kostümkunde 1992. 13-36.

Pillsbury 1967 - Pillsbury. Edmund: Drawings by Vasari and Vincenzo Borghini for the Apparato in Florence in 1565, Master Drawings 5. 1967. 281-283, 330-331.

Pillsbury 1969 - Pillsbury, Edmund: An Unknown Project for the Palazzo Vecchio Courtyard, Mitteilungen des Kunsthistorischen Institutes in Florenz 14. 1969. 57-66.

Radocsay 1964 - Radocsay, Dénes: Österreichische Wappenbriefe der Spätgotik und Renaissance in Budapest, Zeitschrift des Deutschen Vereins für Kunstwissenschaft XVIII. 1964. 91-106.

Radocsay 1965 - Radocsay. Dénes: Renaissance Letters Patent Granting Armorial Bearings in Hungary. Part I, Acta Historiae Artium XI. 1965. 241-264.

Radocsay 1966 - Radocsay, Dénes: Renaissance Letters Patent Granting Armorial Bearings in Hungary. Part II, Acta Historiae Artium XII. 1966. 71-92.

Rauch 2010a - Rauch, Margot: Verkaufte Bräute? Kaiser Ferdinands Töchter zwischen Bild und Welt, in Exh. Cat. Innsbruck 2010, 27-36.

Rauch 2010b - RauCH, Margot: Großherzogin Johanna - „in hochbedrangter kommernis", in Exh. Cat. Innsbruck 2010, 139-144.

RitTER 1887 - RiTTER, Franz: Ein Wiener Schriftmusterbuch aus dem 16. Jahrhundert mit Miniaturmalereien, Mitteilungen des Kais. Königl. Österreichisch Museum für Kunst und Industrie N. F. II. 1887. 337-342.

Rózsa 1960 - Rózsa, György: Oláh Miklós legrégibb arcképe (Járt-e Hans Sebald Lautensack Magyarországon?) [The oldest portrait of Miklós Oláh. Did Hans Sebald Lautensack ever pass through Hungary?], Magyar Könyvszemle 76. 1960. 433-438. (http:// epa.oszk.hu/00000/00021/00242/pdf/MKSZ EPA00021_1960_76_04_428-443.pdf\#page $=\overline{6}$ )

SCHÖNHERR 1890 - RiTTER VON SCHÖNHERR, David: Geschichte des Grabmals Kaisers Maximilian I. und der Hofkirche zu Innsbruck, Jahrbuch der Kunsthistorischen 
Sammlungen des Allerhöchsten Kaiserhauses XI. 1890. 140-268. (http://digi.ub.uni-heidelberg.de/diglit/jbksak1 890/0171? sid=f8e00947387b269060a8ab44aa3b2938)

SCORZA 1985 - SCORZA, R. A.: Vincenzo Borghini and Invenzione. The Florentine Apparato of 1565, Journal of the Warburg and Courtauld Institutes 44. 1985. 57-75.

SEIDL 2010 - SEIDL, Katharina: Herzogin Barbara - „allain, dass mir die waill gar lang ist", in Exh. Cat. Innsbruck 2010. 111-112.

Starn-Partridge 1992 - Starn, Randolph - Partridge, Loren: Arts of Power. Three Halls of State in Italy. 1300_ 1600, Berkeley - Los Angeles - Oxford 1992. (The New Historicism. Studies in Cultural Poetics, 19

STRauss 1975 - The German Single-Leaf Woodcut 1550-1600. Vol. 1, ed. Strauss, L. Walter, New York 1975

Strong 1984 - STRONG, Roy: Art and Power. Renaissance Festivals. 1450-1650, Woodbridge 1984.

SZAKÁLY 1987 - SzAKálY, Ferenc: Egy végvári kapitány hétköznapjai (Horváth Márk szigetvári kapitány levelezése Nádasdy Tamás nádorral és szervitoraival, 1556-1561) The everyday life of the captain of a frontier fortress (The correspondence between Márk Horváth, Captain General of Szigetvár, and Palatine Tamás Nádasdy and his servitors)]. Somogy Megye Múltjából - Levéltári Évkönyv 18 1987. 45-126. (https://library.hungaricana.hu/hu/view/ SOMM Mult 18/?pg=47\&lavout $=\mathrm{s}$

SzÁNTó 1965 - SzÁNTó, Tibor: A betü. A betütörténet és a korszerú betümüvészet rövidáttekintése [The letter. A brief overview of the history of the letter and the modern art of lettering]. 1-2 Budapest 1965. (A Magyar Könyv [The Hungarian Book])

SzováK 2010 - Szovák. Kornél: Gersei Pethő János címerbővítő armálisa [The letters patent (augmentation of arms) of János Pethő de Gerse (I)]. Turul 83. 2010. 97-103.

TÖRÖK 2007 - TÖRÖK G. Zsolt: Renaissance Cartography in EastCentral Europe c. 1450-1650, in WoOdWARD 2007, Part 2.
1806-1851. (http://www.press.uchicago.edu/books/HOC/ HOC_V3_Pt2/HOC_VOLUME3_Part2_chapter61.pdf) TschichoLd 1975 - Das Schreibbuch des Vespasiano Am phiareo. Vespasiano Amphiareo's Writing Book, ed. Tschichold, Jan, Stuttgart - Bad Cannstatt 1975.

VARGA 2007 - VARGA. Szabolcs: Horváth Márk szigeti kapitány hagyatéki leltára 1561-ből [The 1561 bequest inventory of Márk Horváth. Captain General of Szigetvár]. Somogy megye múltjából - Levéltári Evkönyv 38. 2007. 7-17. (http://www.pphf.hu/images/kapcsolat/PEI/horvath.pdf)

Vignau-Wilberg 1969 - Wilberg Vignau-Schutruav, The A. G.: Die emblematischen Elemente im Werke Joris Hoefnagels. Vol. I-II. (Dissertation), Leiden 1969. (Leidse Kunsthistorische Leeks. II)

Vignau-WILberg 1992 - VignaU-WILberg, Thea: George Bocskay, the Calligrapher, in HENDRIX - VIGNAU-WILBERG 1992, 7-13.

VOCELKA 1976 - VOCELKA, Karl: Habsburgische Hochzeiten 1550-1600. Kulturgeschichtliche Studien zur manieristischen Repräsentationsfest, Wien-Köln-Graz 1976. Veröffentlichungen der Kommission für die Neuere Geschichte Österreichs, 65)

VOCELKa 1981 - VOCELKA, Karl: Die politische Propaganda Kaiser Rudolfs II. 1576-1612), Wien 1981. (Veröffentlichungen der Kommission für die Geschichte Österreichs, 9

WoODWARD 2007 - The History of Cartography. Vol. 3. Cartography in the European Renaissance. Part 1-2, ed. WoODWARD, David, Chicago 2007.

WüNsch 1913 - WüNsch, Josef: Der Wiener Maler und Formschneider Donat Hübschman und sein Holzschnittwerk, Mitteilungen der Gesellschaft für Vervielfältigende Kunsı 1913. No. 1, 1-13. (http://digi.ub.uni-heidelberg.de/ $\mathrm{diglit} / \mathrm{mgvk} 1913 / 0005$ ? sid=f8e00947387b269060a8ab $44 a a 3 b 2938)$

\section{NOTES}

${ }^{1}$ This paper is based on my doctoral dissertation (Egy , magyar Zeuxis" Bécsben. Bocskay György (1510 k.-1575) kalligráfus tevékenysége [A "Hungarian Zeuxis" in Vienna. The Art and Life of the Calligrapher George Bocskay (c. 1510-1575)], Budapest, Eötvös Loránd University, 2012). I would like to extend my gratitude to Anton Avar, Anna Bellinazzi $(\uparrow)$, István Fazekas, Géza Galavics, Árpád Mikó, Géza Pálffy, Radoslav Ragač, András Péter Szabó and Edit Szentesi for the generous help they provided me during the preparation of this paper, to the Isabel and Alfred Bader Award for Art History (BaderPreis) of the Hungarian Academy of Sciences (HAS), and to the Coordinated Programme for Study Tours of the HAS and the Slovak Academy of Sciences for supporting my research

${ }^{2}$ Ms. 1561-62 (RitTer 1887; Exh. Cat. Essen-Vienna 1988, No. 600 VIgNAU-WILBERG, Thea]: HeNDrix 1988: HeNDRIX - VignaU-WILBERG 1992); Ms. 1571-73 (RitTer 1887. 341; Chmelarz 1896, 284-285; VignaU-WILBERG 1969, 260 et pass.: Exh. Cat. Essen-Vienna 1988, No. 599 [VIGNAU-WILBERG, Thea]; Exh. Cat. Vienna 2001, No. 17.2 [FAZEKAS, István])

SCHÖNHERR 1890, 217-218; VIGNAU-WILBERG 1992

9-10; Diemer 2004, 54; see also: GulYás 2015; GulYás 2016.

${ }^{4}$ For example ÁLDÁsy 1923, 56-57.

Vienna, 17 April 1558 (MNL OL P 108, Rep. 2-3, Fasc. K, No. 163: Ny. Straub 2000, No. 167; http://adatbazisokonline.hu/adatbazis/cimereslevel-adatbazis, cf. RADOCSAY 1964. 101, 106 [without mention of George Bocskay]; SzÁNTó 1965, 1, 80-81; JAKÓ 1968, 203-204: KOVÁCS 1969, 106-108; VignaU-WILberg 1992. 8; Kovács 1994, 105-106; Exh. Cat. Vienna 2003, No. IV.13 [FAZeKas, István]; Exh. Cat. Budapest-Bratislava 2005, No. VIII-13 [KüNSTLERNÉ VIRÁG, Éva, without mention of George Bocskay]).
The decoration of the other letters patent of Miklós Oláh, issued ten years earlier in Pozsony (Pressburg. Bratislava, today Slovakia): 23 November 1548, MNL OL P 108, Rep. 2-3. Fasc. K No. 162: Ny. Straub 2000, No. 151; http://adatbazisokonline. hu/adatbazis/cimereslevel-adatbazis, of. RADOCSAY 1964, 95 Kovács 1969, 101-106; Kovács 1994, 103-105; Exh. Cat. Vienna 2001, No. 14.2 [FaZeKas, István]; Exh. Cat. Vienna 2003, No. IV.12 [FAZEKAS, István]; Exh. Cat. Budapest-Bratislava 2005, No. VIII-13 [KüNSTLERNÉ VIRÁG, Éva]), cannot, in my estimation, be attributed to the calligrapher.

${ }^{6}$ FAZEKAS 2002; PÁLFFy 2002, 71-74; FAZEKAS 2011 FAZEKAS 2012; FAZEKAS 2013.

7 Letter from George Bocskay to Tamás Nádasdy, Vienna, 9 June 1557 (MNL OL, E 185).

${ }^{8}$ ÖStA AVA FHKA HKA Hoffinanz Ungarn. Rote Nr. 52, Konv. 1587. Dez., fol. 168r. This information was kindly shared by István Fazekas and Géza Pálffy.

${ }^{9}$ ibid., cf. FAZEKAS 2006, 84, note 59. For the Hungarian Council, see: PÁLFFY 2009, 74 et pass.

${ }^{10}$ Perger 1994, 17-18; FAZEKas 2012, 51

${ }^{11}$ PÁLFFY 2002, 72-73: FAZEKAS 2011, 326-327: FAZEKAS 2012, 50-51; FAZEKAS 2013, 105-106, 116-119.

${ }_{12}$ See, among others: Exh. Cat. Schallaburg 1982, 527-539;

Radocsay 1964; Radocsay 1965; Radocsay 1966; Mikó 2005. ${ }^{13}$ cf. КÓTA 1997.

${ }^{14}$ Letter from János Révay to Mihály Révay, Vienna, 14 Mav 1557 (Bratislava, Slovenský národný archív. Rodový archív Révay, Korešpondencia). I thank Géza Pálffy for bring ing this document to my attention.

${ }^{15}$ Letters patent (grant of lands) from Ferdinand I to George Bocskay and Sebestyén Polányi (copy), Vienna, 20 July 1551 
(MNL OL, A 57 [Libri regii], Vol. 2, fol. 421). FAZEKAS 2006, 85, note 62, and Géza Pálffy's kind notification.

16 cf. Fugger 1553, fol. hiVr.

17 "Georgius Bochkaÿ a Razÿnia Sacratissimi ac pontentissimi Principis et domini domini [sic!] Ferdinandi Romanorum imperatoris semper Augusti, ac Germaniae Hungariae Bohemie Dalmatie Croat tie] et Sclauonie, Regis Scriba atq[ue] Aulicus in perpetuam Artis scribendi memoriam Viennae scripsit" (Ms. 1561-62, fol. 118r).

${ }^{18}$ PÁlfFy 2009, 75. For example, in 1557, the title was also granted to the Hungarian humanist János Zsámboky (Johannes Sambucus): ibid.; ALMÁsI 2009, 150.

${ }^{19}$ Letters patent from Ferdinand I to George Bocskay on the granting of the title of royal courtier, Augsburg, 9 May 1559 Archive of the Benedictine Archabbey, Pannonhalma, Archive of the Erdődy family of Vép [Monyórókerék], 22. cs., Fasc. 79, No. 4295). My thanks to András Péter Szabó for alerting me to this document.

${ }^{20}$ Instruction from Ferdinand I to the Hungarian Court Chamber to increase the salary of George Bocskay by 50 Hungarian florins, Vienna, 10 March 1561 (MNL OĹ, E 21, Vol. VIII. fol. 24, cf. KAPOSSY 1956, No. 88).

${ }^{21}$ Ms. 1561-62, fol. 89r; Ms. 1562, fols. 1r, 21r.

22 See note 3.

23 cf. Ms. 1571-73, fol. 48r.

${ }^{24}$ OStA AVA FHKA HKA Hofzahlamtsbücher, Vol. 19 (1564), fols. 19r-19v: Vol. 20. (1565), fol. 147v (cf. BOEHEIM 1888, Reg. No. 5000); Vol. 21. (1566), fols. 122v-123r; Vol. 22. (1567), fol. 117r (cf. BoEHeIM 1888, Reg. No. 5087); Vol. 23. (1568), fols. 170v-171r (cf. BOEHEIM 1888, Reg. No. 5139): Vol. 24. (1570), fol. 209r (cf. Bоенеiм 1888, Reg. No. 5182); Vol. 27. (1573), fol. 121v: Vol. 29. (1575), fol. 137r cf. BoEHEIM 1888, Reg. No. 5314). My thanks to Géza Pálffy for providing these data.

${ }^{25}$ Vienna, 4 June 1558 (Levoča, Spišský archív v Levoči. Horváth-Stansith zo Strážok, bez signatúry).

${ }^{26}$ SZAKÁLY 1987, 46-50; VARGA 2007, 7-8.

27 See note 5 .

${ }^{28}$ According to the note affixed to the letters patent, the document was restored in 1965 in Bratislava.

${ }^{29}$ For his career, see: FAZEKAS 2003, 126; FAZEKAS 2005a: FAZEKAS 2005b: FAZEKAS 2005c; PÁLFFY 2009, 78, et pass.; FAZEKAS 2011, 322, et pass.; FAZEKAS 2012, 50-51; FAZEKAS 2013, 106-107.

${ }^{30}$ For example SzÁNTó 1965, 1. 80-81.

${ }^{31}$ Ms. 1561-62, fol. 99r; Ms. 1562, fols. 9r, 10r.

32 See, among others: JoHNSON 1950, 24-26, 31-36: OGC 1953; Kapr 1956; Doede 1958a, 37-40, 42-43; DoEdE 1958b; CASAMassima 1966; Linke 2004; LinKE-SaUER 2007.

${ }^{33} \mathrm{cf}$. HENDRIX 1992, 34-37.

${ }_{34}$ Ms. 1562 , fols. $29 \mathrm{r}-29 \mathrm{v}$.

35 cf. NEUDÖRFFER $c .1550$, fol. 12

36 cf. AMPHIAREO 1554, fols. BVIIIv-CIr.

37 cf. ARRIGHI 1523 (OGG 1953, 54-55).

$38 \mathrm{cf}$. AMPHIAREO 1554 , fols. BVIIv-BVIIIr.

39 cf. ARright 1523 (OGG 1953, 52-53).

40 cf. Palatino 1561, fol. DVIIv.

$41 \mathrm{cf}$. Palatino 1561, fol. EIIr.

42 cf. AMPHIAREO 1554, fol. BVIIr.

43 cf. AMPHIAREO 1554, fol. BVIr.

${ }^{44}$ Vienna, 14 November 1572 (MNL OL, P 644, No. 2.1.1: http://adatbazisokonline.hu/adatbazis/cimereslevel-adatbazis; Ny. Straub 2000, No. 208; Csízi 2012, 49-51, cf. GuLYÁS 2013a).

${ }^{45}$ PÁlfFy 2002, 78-80; PÁLfFy 2009, 79, et pass.; Csízi 2012, 46-47; PÁLFFY 2013, 69-71.

${ }^{46}$ WÜNSCH 1913; STRAUSS 1975, 435-452.

${ }^{47}$ WüNsch 1913, 1-4. In 1577, for example, he was commissioned by Rudolf II to paint seven pictures for the new court attire, cf. BOEHEIM 1888, Reg. No. 5374.

${ }^{48}$ Rózsa 1960; Strauss 1975, 440; Galavics 1995, 314; Galavics 2001, 66-68: Exh. Cat. Vienna 2001. No. 14.1 (FAZEKAS, István); Exh. Cat. Vienna 2003, No. IV.11 (FAZE-
KAS, István); Exh. Cat. Budapest-Bratislava 2005, No. VIII12 (Ludiková, Zuzana); Exh. Cat. Budapest 2008a, No. II-1 (GöDÖLLE, Mátyás)

${ }^{49}$ Strauss 1975, 448-449; Galavics 1995, 308-309; Exh. Cat. Vienna 2001. No. 16.1/a (FAZEKas. István): Exh. Cat. Vienna 2003, No. VII.27 (Kugler, Georg); Exh. Cat. Bratislava 2009, No. II.1.11-12 (Ludiková, Zuzana): Ludiková 2009: GyUlai 2012: Mikó 2013.

${ }^{50}$ TÖRÖK 2007, 1827, 1836-1837; ALMÁSs 2009, 163, 166.

${ }^{51}$ Buda, 22 September 1507 (MNL OL. O. DI. 86051: NY. Straub 2000, No. 91; Szovák 2010; Csízi 2012, 48-49).

52 See, among others: RADOCSAY 1965, 250-254: RADOCSAY 1966, 76; Exh. Cat. Schallaburg 1982, No. 571 (Straub, Éva); Exh. Cat. Budapest 1994, No. IX-54 (Érszegi, Géza - Mikó, Árpád); Gulyás 2013a.

${ }^{3}$ Petho"'s court hussars also performed protocol duties in attendance to Ferdinand I, in his capacity as King of Hungary, cf. PÁlfFy 2009, 205; PÁlfFy 2013, 44-46.

${ }_{55}$ cf. NEUDÖRFFER $c .1550$, fols. 22-23.

55 cf. Palatino 1561, fol. DVIIIv; AMphiareo 1554, fols. BVIv-BVIIr.

${ }_{56} \mathrm{cf}$. AMPHIAREO 1554, fols. BIVv-BVr.

${ }^{57}$ Vienna, 8 September 1573 (Esztergom, Primatial Archives, Acta Radicalia Cl. T, Nr. 168: BeKE 1995, No. 4; FAZEKAS 2002, 227-228)

${ }^{58}$ FAZEKas 2002, 227-230; FAZEKas 2013, 107; PÁLfFy 2013, 71 .

59 cf. NEUDÖRFFER $c .1550$, fols. 2, 8-9, 14, 22, 28.

${ }^{60}$ See note 3

${ }^{61}$ RaUCH 2010a, 27-36.

${ }^{62}$ RAUCH 2010b, 140; SEIDL 2010, 111

${ }^{63}$ The Habsburg-d'Este marriage contract was signed on 16 October 1564, and the Habsburg-Medici marriage contract was signed on 4 March 1565, cf. VOCELKa 1976, 125126: GROHS 1988, 339.

${ }^{64}$ Also signed in Vienna on the same day was a document in which Joanna declared that, in the event of her death. she renounced her share of the Habsburg legacy, cf. Exh. Cat. Innsbruck 2010, No. 4.17 (KUSTER, Thomas).

${ }^{65}$ Vienna, 1 November 1565 (ÖStA HHStA Urkundenreihen Habsburg-Lothringische Familienurkunden, No. 1355, cf. GULYÁs 2013b).

${ }^{66}$ Vienna, 1 November 1565 (Firenze, Archivio di Stato. Trattati internazionali, V. cf. Exh. Cat. Budapest 2008b. No. 137. [Anna BeLlinAZZI, without mention of George Bocskay]; GULYÁS 2013b)

${ }^{67}$ VocelKa 1976, 126; Grohs 1988, 343-347; Exh. Cat. Innsbruck 2010, No. 1.25 (Kuster, Thomas); SEIDL 2010, 111

${ }^{68}$ Grohs 1988, 347-354; Exh. Cat. Innsbruck 2010, No. 4.16 (Kuster, Thomas): Rauch 2010b, 140-141: SeIDL 2010, 111

${ }^{69}$ Strong 1984, 53; Grohs 1988, 354-363; SEIDL 2010, 111-112; Exh. Cat. Innsbruck 2010, No. 3.12 (SANDBICHLER, Veronika).

${ }^{70}$ Kiss 2004, 105-106. For more about the costumed tournament in Bratislava in 1572, see, among others: DACosTA Kaufmann 1978, 41-43; Vocelka 1981, 128; LiETzManN 1992. 84-101: PfAFFENBICHLER 1992, 31: BeyER 2008, 247: GuLYÁs 2014, 227-228; GuLYús 2017 (in preparation at time of going to print). The coronations of Hungary (1526-1916) are recently examined by the "Lendület" Holy Crown of Hungary Research Project (2012-2017), (led by Prof. Géza Pálffy) of Institute of History. Research Centre for the Humanities. Hungarian Academy of Sciences. The author is a member of the Project.

${ }^{71}$ For contemporary accounts of the festival, $c f$. KATRITZKY 1996, 150-152. Outstanding among them are a printed festival book (MeLLINI 1566), as well as the account that Vasari attached to the 1568 edition of his Vite (CINI 1568). Only a small part of the copious literature on the subject can be listed here: NAGLER 1964, 13-35; Grohs 1988, 363-380; StARN-PARTRIDGE 1992, 168-212, 267-294: CaRsILLO 2006, 246-249; Exh. Cat. Innsbruck 2010, No. 4.16 (Kuster, Thomas), et pass.

${ }^{72}$ See, among others: PILLsbury 1967; Scorza 1985.

73 STARN-PARTRIDGE 1992, 267-294. 
74 Starn-PARTRIDGE 1992, 174-175

${ }^{75}$ Pillabury 1969; Grohs 1988, 374. note 131; Fiorant 2007, 827; Exh. Cat. Innsbruck 2010, No. 1.10 (RAUCH, Margot). 76 STARN-PARTRIDGE 1992, 294-304.

${ }^{77} \mathrm{cf}$. GROHS 1988, 377.

${ }^{78}$ Grohs 1988, 375-380; Exh. Cat. Innsbruck 2010, No. 4.16 (Kuster, Thomas); Rauch 2010b, 141

cf. NEUDÖRFFER c.1550, fols. 22-23.
${ }^{80}$ Florence, 20 December 1565 (ÖStA HHStA Urkundenreihen, Habsburg-Lothringische Familienurkunden, No. 1364; cf. GroHs 1988, 339; Exh. Cat. Innsbruck 2010, No. 4.17 [Kuster, Thomas]).

81 For example Ms. 1561-62, fols. 102r, 119r: Ms. 1562. fol. 14r; Ms. 1571-73, fols. 16r, $92 \mathrm{r}$.

${ }^{82}$ For example Ms. 1561-62, fol. 102v; Ms. 1571-73, fol. $44 \mathrm{r}$.

${ }^{83}$ For example Ms. 1571-73, fols. 31r, 55v. 